\title{
Extra-Skeletal Effects of Vitamin D
}

\author{
Rose Marino and Madhusmita Misra*
}

Pediatric Endocrine Unit, Massachusetts General Hospital and Harvard Medical School, Boston, MA 02114, USA

* Correspondence: mmisra@mgh.harvard.edu; Tel.: +1-617-726-5790

Received: 30 May 2019; Accepted: 25 June 2019; Published: 27 June 2019

\begin{abstract}
The vitamin D receptor is expressed in multiple cells of the body (other than osteoblasts), including beta cells and cells involved in immune modulation (such as mononuclear cells, and activated $\mathrm{T}$ and $\mathrm{B}$ lymphocytes), and most organs in the body including the brain, heart, skin, gonads, prostate, breast, and gut. Consequently, the extra-skeletal impact of vitamin D deficiency has been an active area of research. While epidemiological and case-control studies have often suggested a link between vitamin D deficiency and conditions such as type 1 and type 2 diabetes, connective tissue disorders, inflammatory bowel disorders, chronic hepatitis, food allergies, asthma and respiratory infections, and cancer, interventional studies for the most part have failed to confirm a causative link. This review examines available evidence to date for the extra-skeletal effects of vitamin D deficiency, with a focus on randomized controlled trials and meta-analyses.
\end{abstract}

Keywords: vitamin D; type 1 diabetes; type 2 diabetes; metabolic syndrome; autoimmune; children; cancer

\section{Introduction}

While the skeletal effects of vitamin D are well recognized and described extensively in the literature [1-3], its extra-skeletal effects have been subject to some controversy with conflicting data reported, particularly for case-control or epidemiologic vs. prospective and interventional studies. This review aims to summarize and synthesize data regarding many extra-skeletal effects of vitamin D. Given the extensive literature reported in this area over the last two decades, we have discussed key papers that illustrate variations in data reported from the various kinds of studies, with a focus on randomized controlled trials (RCTs) and meta-analyses of existing studies.

Vitamin $\mathrm{D}_{3}$ (cholecalciferol) is synthesized primarily in the skin on exposure to ultraviolet radiation, while vitamin $\mathrm{D}_{2}$ (ergocalciferol) is derived from plant sources. 7-dehydrocholesterol (provitamin D; present in the stratum basale and stratum spinosum of the epidermis), is converted to previtamin $\mathrm{D}$ on exposure to ultraviolet radiation-B (UV-B), which is then isomerized to vitamin D. Vitamin D passes into dermal capillaries and is carried by vitamin D binding protein (DBP) to the liver, where microsomal vitamin D 25-hydroxylase catalyzes its conversion to 25-hydroxy vitamin $\mathrm{D}$ [25(OH)D], the storage form of vitamin D. $25(\mathrm{OH}) \mathrm{D}$ is what is reported when we ask for levels of vitamin $\mathrm{D}$, and most assays report both $25(\mathrm{OH}) \mathrm{D}_{2}$ and $25(\mathrm{OH}) \mathrm{D}_{3}$. While controversy persists around the normative range for $25(\mathrm{OH}) \mathrm{D}$ levels, the Institute of Medicine has indicated that a 25(OH)D level at or above $20 \mathrm{ng} / \mathrm{mL}$ $(50 \mathrm{nmol} / \mathrm{L})$ is likely sufficient to optimize its skeletal effects [4]. Normative ranges for its possible extra-skeletal effects remain to be determined. Vitamin D supplements may contain either vitamin $\mathrm{D}_{2}$ or $\mathrm{D}_{3}$, or alfacalcidiol (1-hydroxycholecalciferol). Overall, data suggest that vitamin $\mathrm{D}_{3}$ may be more effective in raising $25(\mathrm{OH}) \mathrm{D}$ levels than vitamin $\mathrm{D}_{2}$ (reviewed in [5]).

$25(\mathrm{OH}) \mathrm{D}$ is transported to the kidney by DBP, where cytochromal 25-hydroxyvitamin D 1- $\alpha$ hydroxylase catalyzes its conversion to 1,25 dihydroxy vitamin $\mathrm{D}\left[1,25(\mathrm{OH})_{2} \mathrm{D}\right]$, the active form of vitamin D. The vitamin D receptor (VDR) is expressed in multiple cells including the osteoblasts, mononuclear cells, activated $\mathrm{T}$ and $\mathrm{B}$ lymphocytes and beta cells, and most organs in the body including 
the brain, heart, skin, gonads, prostate, breast, and gut. How vitamin D deficiency affects disease states in these multiple organ systems has been an active area of research. Repletion of vitamin D stores to mitigate and improve disease processes has been attempted in certain conditions, although there is a paucity of data to direct clear treatment protocols, especially in the pediatric population.

\section{Immune and Anti-Inflammatory Effects}

There is evidence that vitamin D modulates B and T lymphocyte function [6-9], and vitamin $\mathrm{D}$ deficiency has been associated with conditions such as multiple sclerosis, type 1 diabetes (T1D), rheumatoid arthritis, systemic lupus erythematosus, dermatomyositis, inflammatory bowel disease, hepatitis, asthma and respiratory infections.

\subsection{Type 1 Diabetes}

Data regarding associations of $25(\mathrm{OH}) \mathrm{D}$ levels or vitamin D sufficiency/insufficiency/deficiency status are conflicting with some [10,11], but not all [12-14], studies reporting an association between low vitamin D status and occurrence of T1D. Pancreatic beta cells have VDRs and express 1- $\alpha$ hydroxylase (encoded by CYP27B1) [15], and the human insulin gene promoter has a vitamin D response element [16]. Further, vitamin D plays a role in T-cell regulatory responses and may protect beta cells from immune attack [17]. In addition, T1D patients are reported to have lower 25(OH)D levels compared to age matched controls [11,18,19]. Cooper et al. [20] linked the genetic determinants of circulating 25(OH)D (DHCR7 and CYP2R1, which encode 7-dehydrocholesterol reductase and 25-hydroxylase) and vitamin D signaling in T cells (CYP27B1) with risk of T1D, while others (including a meta-analysis of nine studies with 1053 patients and 1017 controls) have linked specific polymorphisms of the VDR gene with risk for T1D [21]. Another study linked T-cell proliferation with DBP, and reported higher levels and frequencies of serum anti-DBP antibodies in patients with T1D vs. controls. This study postulated that DBP (expressed in $\alpha$-cells of pancreatic islets) may be an autoantigen in T1D [22]. Further, lower maternal third trimester DBP levels and cord blood DBP levels have been associated with risk of T1D in offspring [23,24]. Further investigation into the role of CYP27B1 in immune cells such as monocytes, macrophages and T-cells is needed to better understand the role of vitamin $\mathrm{D}$ in the pathogenesis and perhaps prevention of T1D. Under this umbrella of research, prospective studies of vitamin D supplementation have attempted to elucidate causality of T1D and use of vitamin D as a potential therapy.

Interventional studies: Table 1 describes details of some representative studies of vitamin D supplementation in T1D. a beneficial effect of cholecalciferol supplementation on regulatory T-cells (T-regs) has been reported, with an increase in T-reg percentage [25] and suppressive capacity [26], and reduced progression to undetectable C-peptide. Consistent with these findings, a meta-analysis of five observational studies reported a protective effect of vitamin D supplementation in early childhood against development of T1D with a dose response effect [27], while another reported that such supplementation may have prevented 27\% of the predicted T1D cases in England and Wales in 2012 [28]. Similarly, a beneficial impact has been reported with respect to fasting C-peptide with lower daily insulin doses [29], peripheral vascular resistance and inflammatory renal markers [30]. However, many other studies have not demonstrated a beneficial effect of vitamin D supplementation in preventing or improving the course of T1D. Importantly, the prospective Environmental Determinants of Diabetes in the Young (TEDDY) Study demonstrated no benefit of maternal vitamin D supplementation during pregnancy on the risk of islet autoimmunity in the offspring [31]. Other studies have failed to demonstrate a beneficial impact on beta cell function [32], HbA1C levels [25,33,34] or insulin requirement $[25,34]$. While the reason for these conflicting results is unclear, one may speculate that differences in study design, sample size and vitamin D dosing may contribute. Overall, randomized controlled studies investigating vitamin D replacement in preventing T1D or treating at diagnosis to prolong endogenous insulin secretion are few. Vitamin D replacement is necessary in those deficient for optimal bone health. However, current data do not provide definitive evidence that supplementation will improve the inflammatory state in a clinically significant manner. 
Table 1. Summary of studies of vitamin D administration in type 1 and type 2 diabetes.

\begin{tabular}{|c|c|c|c|c|}
\hline Reference & Type of Study & Intervention & Participants & Results (Intervention) \\
\hline \multicolumn{5}{|c|}{ Type 1 Diabetes } \\
\hline \multicolumn{5}{|c|}{ Studies examining effects on immune modulation } \\
\hline [25] & $\begin{array}{l}\text { 18-month randomized } \\
\text { controlled trial }(\mathrm{RCT})\end{array}$ & 2000 IUs vitamin $D_{3}$ daily or placebo & $\begin{array}{l}38 \text { participants; } 35 \text { completers; } \\
7-30 \text { years old }\end{array}$ & $\begin{array}{c}\text { Increase in regulatory T-cell (T-reg) percentage; lower } \\
\text { cumulative incidence of progression to undetectable } \\
\text { C-peptide; no difference in HbA1C, insulin } \\
\text { requirement or BMI }\end{array}$ \\
\hline [26] & 12-month RCT & $70 \mathrm{IUs} / \mathrm{kg} /$ day vitamin $\mathrm{D}_{3}$ vs. placebo & $\begin{array}{l}29 \text { Participants; }>6 \text { years old; } \\
<3 \text { months duration of T1D }\end{array}$ & Increase in suppressive capacity of T-regs \\
\hline \multicolumn{5}{|c|}{ Studies of prevention of islet autoimmunity or T1D } \\
\hline [27] & $\begin{array}{l}\text { Meta-analysis of four case-control } \\
\text { and one cohort study }\end{array}$ & $\begin{array}{l}\text { Vitamin D supplementation } \\
\quad \text { (variable doses) }\end{array}$ & Infants & $\begin{array}{c}\text { Four case control studies: risk of T1D decreased; } \\
\text { similar findings in cohort study; some evidence of } \\
\text { a dose-response effect }\end{array}$ \\
\hline [28] & $\begin{array}{l}\text { Population impact number of } \\
\text { eliminating a risk factor } \\
\text { (PIN-ER-t) Statistical method }\end{array}$ & $\begin{array}{l}\text { Vitamin D supplementation } \\
\text { (variable doses) }\end{array}$ & Babies born in 2012 & $\begin{array}{l}\text { For a population of } 729,674 \text { babies born in England } \\
\text { and Wales in 2012, } 374 \text { cases of T1D (out of } 1357 \text { total } \\
\text { predicted cases) could be prevented over } 18 \text { years if all } \\
\text { were supplemented with vitamin D }\end{array}$ \\
\hline [31] & $\begin{array}{l}\text { Cohort study; assessment every } \\
3 \text { months between } 3-48 \text { months, } \\
\text { and then every } 6 \text { months }\end{array}$ & $\begin{array}{l}\text { Maternal vitamin D supplementation } \\
\text { during pregnancy (based on recall); } \\
\text { cumulative intake of vitamin D } \\
\text { supplements and n-3 FAs analyzed }\end{array}$ & $\begin{array}{l}8676 \text { children with increased } \\
\text { genetic risk for T1D in Finland, } \\
\text { Germany, Sweden and the US }\end{array}$ & $\begin{array}{l}\text { Vitamin D supplementation during pregnancy was } \\
\text { not associated with risk for development of islet } \\
\text { autoantibodies (any/none and cumulative intake) }\end{array}$ \\
\hline \multicolumn{5}{|c|}{ Studies examining course or complications of T1D } \\
\hline [29] & 6-month RCT & $\begin{array}{l}0.25 \mathrm{mcg} \text { twice daily of alfacalcidol } \\
\text { vs. placebo }\end{array}$ & $\begin{array}{c}61 \text { participants; } 54 \text { completers; } \\
8-15 \text { years old; }<8 \text { weeks duration } \\
\text { of T1D }\end{array}$ & Higher fasting C-peptide; lower daily insulin dose \\
\hline [30] & $\begin{array}{l}\text { 12-24 weeks single arm } \\
\text { intervention study }\end{array}$ & $1000-2000$ IUs of vitamin $D_{3}$ daily & $\begin{array}{l}271 \text { adolescents with T1D with } \\
25(\mathrm{OH}) \mathrm{D}<15 \mathrm{ng} / \mathrm{mL}\end{array}$ & $\begin{array}{l}\text { Improved endothelial function; decreased urinary } \\
\text { inflammatory cytokines/chemokines; no change } \\
\text { in systolic or diastolic blood pressure, lipids, HbA1C } \\
\text { and albumin/creatinine ratio }\end{array}$ \\
\hline [32] & 2-year RCT & $0.25 \mathrm{mcg}$ daily of calcitriol or placebo & $\begin{array}{l}34 \text { participants } 11-35 \text { years old with } \\
\text { recent onset T1D and high basal } \\
\text { C-peptide }\end{array}$ & No effect on beta cell function \\
\hline [33] & $\begin{array}{l}\text { Single dose single arm } \\
\text { intervention study }\end{array}$ & $\begin{array}{l}\text { Vitamin } D_{3} \text { : } \\
\text { 100,000 IUs for those } 2-10 \text { years old; } \\
160,000 \text { IUs for those }>10 \text { years }\end{array}$ & $\begin{array}{l}40 \text { children }<19 \text { years with T1D and } \\
\text { vitamin D deficiency }(<20 \mathrm{ng} / \mathrm{mL}) \\
\text { included in ITT analysis }\end{array}$ & No difference in $\mathrm{HbA} 1 \mathrm{C}$ levels at 3 months or at 1 year \\
\hline [34] & 6-month RCT & $\begin{array}{l}\text { Vitamin } \mathrm{D}_{3} 60,000 \text { IUs once a month } \\
\text { for } 6 \text { months }\end{array}$ & 52 children with T1D 1-18 years old & $\begin{array}{l}\text { Higher mean C-peptide level; no difference in } \mathrm{HbA} 1 \mathrm{C} \\
\text { or insulin requirement }\end{array}$ \\
\hline
\end{tabular}


Table 1. Cont.

\begin{tabular}{|c|c|c|c|c|}
\hline Reference & Type of Study & Intervention & Participants & Results (Intervention) \\
\hline \multicolumn{5}{|c|}{ Obesity, Prediabetes or Type 2 Diabetes } \\
\hline \multicolumn{5}{|c|}{ Adults } \\
\hline [35] & Single arm intervention study & $\begin{array}{l}\text { Vitamin } \mathrm{D}_{3} \text { two doses of } 100,000 \mathrm{IUs} \\
\text { at 2-week intervals }\end{array}$ & $\begin{array}{c}33 \text { adults with vitamin } \mathrm{D} \text { deficiency } \\
(25(\mathrm{OH}) \mathrm{D}<20 \mathrm{ng} / \mathrm{mL}) \text { and } \\
\text { without } \mathrm{T} 2 \mathrm{D}\end{array}$ & $\begin{array}{l}\text { No change in mean blood glucose or insulin, or insulin } \\
\text { sensitivity (assessed using an OGTT) }\end{array}$ \\
\hline [36] & 6-month RCT & Vitamin $\mathrm{D}_{3} 4000$ IUs daily or placebo & $\begin{array}{l}82 \text { insulin resistant, vitamin } \mathrm{D} \\
\text { deficient }(25(\mathrm{OH}) \mathrm{D}<20 \mathrm{ng} / \mathrm{mL}) \\
\text { South Asian women in New } \\
\text { Zealand without T2D }\end{array}$ & $\begin{array}{l}\text { HOMA-IR improved when } 25(\mathrm{OH}) \mathrm{D} \text { level rose to } \\
>32 \mathrm{ng} / \mathrm{mL} \text {; no differences in insulin secretion, CRP, } \\
\text { BMI or lipid levels }\end{array}$ \\
\hline [37] & 6-month intervention study & $\begin{array}{l}\text { Vitamin } \mathrm{D}_{3} 20,000 \text { IUs or placebo } \\
\text { given twice weekly over } 6 \text { months }\end{array}$ & $\begin{array}{l}104 \text { adults with vitamin } \mathrm{D} \\
\text { deficiency; } 94 \text { completers }\end{array}$ & $\begin{array}{l}\text { No difference in insulin secretion, insulin sensitivity } \\
\text { (using a hyperglycemic clamp) or lipids }\end{array}$ \\
\hline [38] & 4-month RCT & Vitamin $\mathrm{D}_{3} 2500$ IUs or placebo daily & $\begin{array}{l}114 \text { post-menopausal women with } \\
25(\mathrm{OH}) \text { D between } 10-60 \mathrm{ng} / \mathrm{mL}\end{array}$ & $\begin{array}{l}\text { No improvement in blood pressure, endothelial } \\
\text { function, arterial stiffness, inflammation and CRP }\end{array}$ \\
\hline [39] & 16-week RCT & $\begin{array}{l}\text { Vitamin } \mathrm{D}_{3} \text { supplementation } 200 \mathrm{IUs} \\
\text { or placebo daily }\end{array}$ & 165 healthy women 18-35 years & $\begin{array}{l}\text { No change in lipids; modest change in systolic and } \\
\text { diastolic blood pressure }\end{array}$ \\
\hline [40] & 5-year RCT & $\begin{array}{l}\text { Vitamin } \mathrm{D}_{3} 20,000 \mathrm{IUs} / \text { week or } \\
\text { placebo; followed every } 6 \text { months }\end{array}$ & $\begin{array}{l}556 \text { adults } 25-80 \text { years old with } \\
\text { prediabetes; } 503 \text { completers }\end{array}$ & $\begin{array}{c}25(\mathrm{OH}) \mathrm{D} \text { increased from } \sim 24 \mathrm{ng} / \mathrm{mL} \text { to } 48 \mathrm{ng} / \mathrm{mL} \text { with } \\
\text { supplementation; no effect on progression to T2D, } \\
\text { measures of glucose metabolism, serum lipids or } \\
\text { blood pressure in the group as a whole, or in those } \\
\text { with vitamin D deficiency }\end{array}$ \\
\hline [41] & Pooled meta-analysis of 28 RCTs & $\begin{array}{l}\text { Vitamin } \mathrm{D}_{3} \text { supplementation, } \\
\text { variable doses }\end{array}$ & Adults at risk for T2D (no T2D) & $\begin{array}{l}\text { No effect on controlling fasting plasma glucose levels, } \\
\text { improving insulin resistance, or preventing T2D; } \\
\text { stratified analysis suggested a possible beneficial effect } \\
\text { in those without obesity, those with prediabetes, } \\
\text { when } 25(\mathrm{OH}) \mathrm{D} \text { levels were } \geq 20 \mathrm{ng} / \mathrm{mL} \text {, and when the } \\
\text { supplemental dose was }>2000 \mathrm{IUs} \text { per day and given } \\
\text { without calcium supplementation }\end{array}$ \\
\hline [42] & $\mathrm{RCT}$ & $\begin{array}{l}\text { Vitamin } D_{3} 4000 \text { IUs or placebo } \\
\text { regardless of vitamin D status }\end{array}$ & $\begin{array}{l}2423 \text { adult participants meeting } \\
\text { criteria for prediabetes } \\
\text { ( } 2382 \text { randomized })\end{array}$ & $\begin{array}{c}\text { No differences in baseline } 25(\mathrm{OH}) \mathrm{D} \text {; supplemented } \\
\text { group had } 25(\mathrm{OH}) \mathrm{D} \text { levels about twice that in the } \\
\text { placebo group; no difference in progression to T2D } \\
\text { ( } 9.4 \text { vs. } 10.7 \text { events per } 100 \text { person-years respectively } \\
\text { at a median follow-up of } 2.5 \text { years) }\end{array}$ \\
\hline \multicolumn{5}{|c|}{ Children } \\
\hline [43] & 6-month RCT & Vitamin $\mathrm{D}_{3} 4000$ IUs daily or placebo & $\begin{array}{l}35 \text { adolescents with obesity 9-19 } \\
\text { years old }\end{array}$ & $\begin{array}{l}\text { Improved HOMA-IR and QUICKI (but not fasting } \\
\text { glucose, HbA1C, CRP, IL-6 or TNF-alpha) in those } \\
\text { who received vitamin D }\end{array}$ \\
\hline [44] & $\begin{array}{l}\text { 1-year open label parallel arm } \\
\text { prospective study }\end{array}$ & $\begin{array}{l}\text { Vitamin } D_{3} 5000 \text { IUs weekly for } 8 \\
\text { weeks vs. no intervention }\end{array}$ & $\begin{array}{l}70 \text { indigenous Argentinean children } \\
\text { vs. } 20 \text { non-supplemented children }\end{array}$ & Improved HDL \\
\hline
\end{tabular}


Table 1. Cont

\begin{tabular}{|c|c|c|c|c|}
\hline Reference & Type of Study & Intervention & Participants & Results (Intervention) \\
\hline [45] & 12-week RCT & $\begin{array}{l}\text { Vitamin } \mathrm{D}_{3} 300,000 \text { IUs weekly } \\
\text { or placebo }\end{array}$ & $\begin{array}{l}50 \text { children with obesity } \\
10-16 \text { years old }\end{array}$ & $\begin{array}{l}\text { Improved serum insulin and HOMA-IR with no effect } \\
\text { on lipids, fasting blood sugar or blood pressure }\end{array}$ \\
\hline [46] & Retrospective study & Vitamin D supplementation & $\begin{array}{l}43 \text { children } 3-18 \text { years old with T2D } \\
\text { for }>12 \text { months and a diagnosis of } \\
\text { vitamin } D \text { deficiency } \\
(25(\mathrm{OH}) \mathrm{D}<20 \mathrm{ng} / \mathrm{mL})\end{array}$ & $\begin{array}{l}\text { Decrease in BMI-SDS, HbA1C and ALT } \\
\text { in supplemented group }\end{array}$ \\
\hline [47] & 12-week RCT & Vitamin $\mathrm{D}_{3} 2000$ IUs daily or placebo & $\begin{array}{l}58 \text { adolescents with obesity } 12-18 \\
\text { years old }\end{array}$ & $\begin{array}{l}\text { No change in fasting glucose, insulin, HOMA-IR, } \\
\text { lipids or CRP }\end{array}$ \\
\hline [48] & 12-week RCT & $\begin{array}{l}\text { Vitamin } \mathrm{D}_{3} \text { two doses ( } 400 \mathrm{IU} / \text { day } \\
\text { and } 2000 \mathrm{IU} / \text { day) for } 12 \text { weeks }\end{array}$ & $\begin{array}{l}51 \text { Caucasian adolescents with } \\
\text { obesity } 12-18 \text { years old; } \\
46 \text { completers }\end{array}$ & $\begin{array}{l}\text { No change in } 25(\mathrm{OH}) \mathrm{D} \text { levels in the in } 400 \mathrm{IU} / \text { day } \\
\text { group and a modest increase in the } 2000 \mathrm{IU} / \text { day group. } \\
\text { No change in fasting HOMA-IR, insulin, glucose or } \\
\text { lipid levels post-supplementation }\end{array}$ \\
\hline [49] & 2-year prospective study & $\begin{array}{l}\text { Vitamin } D_{3} 100,00 \text { IUs/year to } \\
\text { both groups }\end{array}$ & $\begin{array}{l}104 \text { children in Group a (treated } \\
\text { in 2014) and } 86 \text { in Group B } \\
\text { (treated in 2013) }\end{array}$ & $\begin{array}{l}\text { Changes in } 25(\mathrm{OH}) \mathrm{D} \text { levels were significantly } \\
\text { associated with lower LDL-C and Apo-B levels. }\end{array}$ \\
\hline [50] & $\begin{array}{l}\text { 3-month open label, } \\
\text { prospective study }\end{array}$ & $\begin{array}{l}\text { Vitamin } \mathrm{D}_{3} 100,000 \text { IUs monthly for } \\
3 \text { months }\end{array}$ & $\begin{array}{l}19 \text { children with obesity and } \\
\text { vitamin } D \text { deficiency } \\
13-18 \text { years old }\end{array}$ & $\begin{array}{l}\text { No change in endothelial function, fasting lipids, } \\
\text { glucose, insulin and CRP values }\end{array}$ \\
\hline [51] & 12-week RCT & $\begin{array}{l}\text { Vitamin } \mathrm{D}_{3} \text { at either } 0,400,1000,2000 \\
\text { or } 4000 \mathrm{IU} / \text { day for } 12 \text { weeks }\end{array}$ & $\begin{array}{c}323 \text { early pubertal children } \\
\text { At baseline, } 15 \% \text { had } 25(\mathrm{OH}) \mathrm{D} \\
\text { levels that were insufficient } \\
<25 \mathrm{ng} / \mathrm{mL}, 6 \% \text { had levels } \\
<16 \mathrm{ng} / \mathrm{mL} \text { and } 1 \% \text { had levels lower } \\
\text { than } 12 \mathrm{ng} / \mathrm{mL}\end{array}$ & $\begin{array}{c}\text { At baseline, 25(OH)D levels were inversely associated } \\
\text { with insulin and HOMA-IR. However, glucose, insulin } \\
\text { and insulin resistance increased over } 12 \text { weeks in all } \\
\text { dosage groups }\end{array}$ \\
\hline [52] & 12-week RCT & $\begin{array}{l}\text { Vitamin } \mathrm{D}_{3} 50,000 \text { IUs per week } \\
\text { vs. placebo }\end{array}$ & $\begin{array}{l}29 \text { African American children with } \\
\text { obesity } 13-17 \text { years old }\end{array}$ & No impact on insulin secretion or sensitivity \\
\hline
\end{tabular}




\subsection{Multiple Sclerosis}

The risk for multiple sclerosis (MS) is higher in people living above $35^{\circ}$ latitudes than those who live below this latitude [53] (although effects were attenuated over time in this study), and studies have reported an association between risk for MS and lower sunlight exposure [54-59], vitamin D intake [60] and serum 25(OH)D levels [61-64]. Increased sun exposure in children has been linked to a lower risk of MS in studies out of Tasmania [57], twin studies where only one monozygotic twin developed MS [55], a study from Cuba, Martinique and Sicily [54], as well as studies in adults from Iran [58] and Sweden [59]. Other studies have linked the reduced risk of MS following sun exposure to the melanocortin 1 receptor genotype [56]. Further, polymorphisms in genes that impact 25(OH)D levels have been linked to risk of relapse in children with MS [65].

Munger et al. reported an inverse relationship between serum 25(OH)D and the risk of MS [61], and that before onset, MS risk decreases by $40 \%$ for every $20 \mathrm{ng} / \mathrm{mL}$ increase in 25(OH)D levels. In another study, women (but not men) with MS had lower 25(OH)D levels than controls 11 years after disease onset [62], with a 19\% reduction in the odds for MS for every $4 \mathrm{ng} / \mathrm{mL}$ increase in winter $25(\mathrm{OH}) \mathrm{D}$ concentrations. Similar lower 25(OH)D in patients with MS versus controls has been reported in other studies for winter [63] or summer levels [64].

Data suggest that vitamin D sufficient states in the mother and infant may protect against MS [66]. Increased first trimester exposure to UVR reduced MS risk in the child in a dose dependent fashion [67]. Higher MS rates in children born in the summer or spring, and lower rates in those born in the fall may be related to maternal vitamin D insufficiency [68,69]. In the Nurses Health Study, women born to mothers with high vitamin D intake during pregnancy had a reduced risk of MS [70].

Interventional Studies: protective effects of vitamin D supplementation have been demonstrated against MS in a few studies [60]. The Nurses Health Study reported that women taking at least $400 \mathrm{IU}$ of vitamin D supplements daily were at lower risk compared to those not on supplements [60,71]. a meta-analysis of 12 RCTs that included 950 adult patients with MS reported non-significant trends in improvement in annualized relapse rate Expanded Disability Status Scale scores and MRI findings in those who received vitamin D supplementation, although higher vitamin D doses (2850-10,400 IUs) performed significantly worse compared to lower doses (800-1000 IUs) [72]. One RCT did report an improvement in MRI lesions when vitamin $\mathrm{D}_{3}$ was employed as add-on treatment to interferon beta-1b in patients with MS [73]. Data are lacking for effects of vitamin D supplementation in children with MS.

Overall, although case-control and epidemiological studies suggest that people with lower 25(OH)D levels may be at higher risk for MS, confounding factors, such as the association of higher latitudes (also a risk factor for MS) with lower 25(OH)D levels need to be considered. Interventional studies examining the preventive effect of vitamin D supplementation on the risk for developing MS are lacking. Existing RCTs in adult patients with established MS are not convincing for a significant role for vitamin D supplementation in reducing MS outcomes, although trends for a positive effect have been reported, particularly with low dose supplementation. Data to date indicate deleterious effects of high dose vitamin D supplementation on MS outcomes. RCTs assessing the impact of vitamin D supplementation on MS outcomes in children are lacking.

\subsection{Rheumatoid Arthritis}

One meta-analysis of 15 studies (including 1143 rheumatoid arthritis (RA) patients and 963 controls) confirmed lower 25(OH)D levels and a higher prevalence of vitamin D deficiency in patients compared with controls (55\% vs. 33\%) [74]. Similarly, a meta-analysis of three cohort studies that included 215,757 participants and 874 incident cases of RA reported that individuals in the highest quartile for vitamin D intake had a $24 \%$ lower risk of developing RA compared to those in the lowest quartile [75]. In addition, inverse associations of $25(\mathrm{OH}) \mathrm{D}$ levels with disease activity scores in RA patients have been reported [74,76-79]. Further, specific VDR polymorphisms have been demonstrated to contribute significantly to RA risk $[80,81]$. 
Interventional Studies: consistent with the findings from epidemiologic studies, protective effects of vitamin D supplementation have been demonstrated against RA in some studies [82]. Chandrashekara and Patted reported a reduction in disease severity scores following vitamin D replacement (60,000 IU of vitamin D weekly for six weeks followed by 60,000 IU monthly) over three months in RA patients who were vitamin D deficient $(25(\mathrm{OH}) \mathrm{D}$ levels $<20 \mathrm{ng} / \mathrm{mL})$ and had persistent disease activity [83]. However, a meta-analysis that included five RCTs in patients with RA reported borderline significance for reduction in disease recurrence, but not for disease activity [84]. Calcitriol enhances inhibition of T cell activation by abatacept (CTLA-4-Ig), a CD28-ligand blocker to which patients with RA respond with variable efficacy [85], suggesting that vitamin D or calcitriol may be used as an adjunct therapy to improve efficacy of abatacept in RA patients. Overall, these data suggest that lower $25(\mathrm{OH}) \mathrm{D}$ levels may predict susceptibility to RA and its severity, but it is not clear that vitamin D supplementation reduces the risk of developing RA or its disease activity/severity. Further, data in children with RA are currently lacking.

\subsection{Systemic Lupus Erythematosus (SLE) and Juvenile Dermatomyositis}

Many studies have reported inverse associations of 25(OH)D levels with the occurrence and severity of SLE and dermatomyosits in adults and children [86-92]. In children, greater disease severity of SLE is reported in those with 25(OH)D levels $<20 \mathrm{ng} / \mathrm{mL}$ [88].

Interventional Studies: in contrast to other autoimmune conditions, several interventional studies have reported an improvement in markers of severity of disease following vitamin D supplementation in patients with SLE. One study in adolescents and adults with juvenile onset SLE reported an improvement in disease severity scores and fatigue in those randomized to 50,000 IU per week of vitamin D supplementation compared to placebo over 6 months [93]. Similar findings are reported in studies of adults with SLE. a reduction in inflammatory and hemostatic markers, and disease activity was reported in those randomized to 2000 IU of vitamin D daily compared to placebo for 12 months [94]. Further, a meta-analysis of three RCTs of vitamin D supplementation in patients with SLE reported a significant reduction in anti-dsDNA positivity with supplementation [84]. Another study reported an increase of T-regs and a decrease of effector Th1 and Th17 cells, memory B cells and anti-DNA antibodies in adults with SLE given 100,000 IU of vitamin D weekly for 4 weeks followed by 100,000 IU monthly for 6 months [95]. No flares were observed over the study duration [95].

Overall, these data suggest that low 25(OH)D levels are concerning for greater risk of developing SLE and increased severity of the condition, and a possible beneficial effect of vitamin D supplementation on disease severity, particularly when levels are low. However, more RCTs, including in children, are necessary to confirm these data. Of note, symptoms of SLE can worsen after UV radiation exposure which will otherwise increase the vitamin D status of the individual [96]. Thus, excessive sun exposure to improve 25(OH)D levels in patients with SLE may worsen symptoms of the disease.

\subsection{Psoriasis}

Keratinocytes express the vitamin D receptor (VDR), and vitamin D inhibits the growth of keratinocytes, stimulates them to differentiate, and helps maintain the cutaneous barrier integrity [97]. This has led to the use of topical vitamin D analogs to treat psoriasis [98]. However, no VDR genotype (other than the Taql polymorphsm in Caucasians) has been linked to an increased risk for psoriasis $[99,100]$. In addition, there is no correlation between the change in $25(\mathrm{OH}) \mathrm{D}$ post phototherapy and change in severity of symptoms of psoriasis [101,102].

Interventional Studies: a 6-month RCT of 60,000 IUs of vitamin D vs. placebo given every 2 weeks to 45 patients with psoriasis showed an increase in $25(\mathrm{OH}) \mathrm{D}$ levels in the active group associated with a reduction in the Psoriasis Area and Severity Index (PASI) [103]. Topical vitamin D analogs (calcipotriene/calcipotriol/maxacalcitol) given with topical betamethasone have also been shown to be effective in improving plaque psoriasis [104-106] by disrupting the IL-36 and IL-23/IL-17 positive feedback loop, key factors in the pathogenesis of psoriasis. 
Overall, while studies suggest an association between 25(OH)D levels and psoriasis, causation is yet to be established. Additionally, RCTs to date are promising for an impact of vitamin D on psoriasis severity, but studies are small, and more and larger RCTs are necessary to confirm these preliminary findings. Data in children are lacking.

\subsection{Inflammatory Bowel Disease (IBD)}

Protective effects of vitamin D supplementation have been demonstrated against IBD [107]. Vitamin D deficient and vitamin D receptor $(V d r)$ null mice are at high risk of IBD [108], with more severe disease and more spontaneous recurrences. Further, polymorphisms in the $V d r$ gene (TaqI) may confer susceptibility to IBD [109]. a meta-analysis of VDR genotyping in relation to IBD reported that ApaI polymorphism may increase the risk of Crohn's disease, whereas the TaqI polymorphism may decrease the risk of ulcerative colitis, especially in Caucasians [110]. a connection has been proposed between seasonal vitamin D status and risk for both Crohn's disease and ulcerative colitis [111,112], with an association between vitamin D deficiency and more complicated disease course. a recent meta-analysis reported lower 25(OH)D levels in patients with both Crohn's disease and ulcerative colitis than controls, a two-fold risk of vitamin D deficiency in those with IBD, and greater severity of Crohn's disease in those with vitamin D deficiency $[113,114]$. However, these studies are associative and confounded by the fact that malabsorption (particularly in Crohn's disease) may contribute to lower 25(OH)D levels, with more severe disease being associated with more malabsorption.

Interventional studies: there are few randomized controlled trials that have examined the impact of vitamin D supplementation on disease occurrence or severity. One randomized controlled trial of 400 vs. $2000 \mathrm{IU}$ of vitamin D supplementation in children and adolescents with IBD did report that the higher dose of vitamin D led to lower levels of pro-inflammatory markers [115]. Vitamin D has also been shown to exert marked anti-inflammatory effects on peripheral and intestinal CD4+ and CD8+ T cells of patients with inflammatory bowel disorders in vitro, and inhibit production of TH1 and TH17 cytokines in patients with Crohn's disease in vivo [116].

Overall, while data to date suggest that vitamin D deficiency may impact disease course in patients with inflammatory bowel disorders, we are in need of robust RCTs that will help determine whether vitamin D supplementation is indeed efficacious in reducing disease severity in these patients, including in children.

\subsection{Food Allergies}

Although associations of low 25(OH)D levels with a risk of atopy, asthma and food allergies have been reported [117], recent birth cohort studies demonstrate no association of 25(OH)D levels (including antenatal vitamin D exposure) with the incidence of food allergy $[118,119]$. One meta-analysis of more than 5000 children did not find a significant association between vitamin D status and food allergy [120].

Interventional Studies: data for the role of vitamin D supplementation in preventing food allergies is inconsistent, and large trials are necessary to determine the role if any of vitamin D in reducing the risk for food allergies [121]. One RCT of 400 vs. 1200 IUs of vitamin D supplementation in 975 infants from the age of 2 weeks found no impact of higher-dose vitamin D supplementation on allergic sensitization or allergic diseases (food or aeroallergen) at 12-months of age [122]. Overall, current data do not support a role of vitamin D status in impacting the risk for food allergies in children, and non-interventional studies may be confounded by variables such as associated malabsorption.

\subsection{Chronic Hepatitis $B$ and $C$}

Certain vitamin $D$ receptor gene ( $V D R$ a/a) polymorphisms have been linked to greater severity of hepatitis B infection and a higher viral load [123]. In addition, polymorphisms in the T/T allele of exon 9 of the VDR gene (but not intron 8 polymorphisms) are associated with occult hepatitis B infection [124]. Further, a meta-analysis of seven studies involving 814 patients with chronic hepatitis B and 696 controls showed lower 25(OH)D levels in patients with chronic hepatitis B associated with higher viral 
loads [125]. Petta et al. [126] reported that lower 25(OH)D levels in chronic hepatitis $\mathrm{C}$ infection were related to decreased CYP27A1 expression, female gender, necrosis and inflammation, severe fibrosis and poor viral response to interferon based therapy. Of note, polymorphisms in the VDR gene have been associated with development of hepatocellular carcinoma in patients with hepatitis C [127].

Interventional Studies: in in vitro studies, $25(\mathrm{OH}) \mathrm{D}$ has been shown to inhibit hepatitis $\mathrm{C}$ virus production by suppressing apolipoprotein expression [128]. In 42 patients with recurrent hepatitis $C$ infections treated with INF- $\alpha$ and ribavirin for 48 weeks, vitamin D deficiency was associated with an unfavorable response to antiviral medication, and 15 patients given oral vitamin D supplements had a better and more sustained response to antiviral treatment [129]. One short 6-week RCT of vitamin $D$ supplementation vs. placebo in 54 patients with chronic hepatitis $C$ with vitamin D deficiency demonstrated improved serum markers of hepatic fibrogenesis upon correction of 25(OH)D levels [130].

Overall, data suggest deleterious effects of vitamin D deficiency on the course of chronic hepatitis $\mathrm{B}$ and $\mathrm{C}$ infections, with some studies suggesting a possible role (and mechanism) for vitamin D supplementation in improving outcomes in these patients. However, we are in need of larger RCTs and of longer duration to effectively confirm these findings, and data in children are lacking.

\subsection{Asthma and Respiratory Infections}

Several studies have reported an association between vitamin D deficiency $(25(\mathrm{OH}) \mathrm{D}<20 \mathrm{ng} / \mathrm{mL})$ and increased airway inflammation, decreased lung function, increased exacerbations, and poor prognosis in patients with asthma (reviewed in [131]).

Interventional Studies: a literature review of RCTs of vitamin D supplementation in children older than 2 years found a possible effect of vitamin D supplementation in improving bronchial asthma exacerbation [132,133], but no effect on the severity of asthma [132]. a subsequent meta-analysis that included 435 children (seven trials) and 658 adults (two trials) similarly reported a reduction in asthma exacerbations requiring systemic corticosteroids and the risk for an exacerbation requiring an emergency department visit or hospitalization in those who received vitamin D supplementation, but not on measures of severity (\% predicted forced expiratory volume in one second or Asthma Control test Scores [134]. The improvement in asthma exacerbation has been attributed to a decrease in respiratory infections [12].

RCTs of vitamin D supplementation (300-1200 IUs per day) vs. placebo report a potential effect of vitamin D in reducing the risk for influenza infections during the winter months [135], although a subsequent analysis reported that benefits observed in the first month of supplementation were lost in the second month, and overall there was no difference among groups for influenza prevalence over the entire season [136]. a meta-analysis of 25 RCTs using vitamin D supplementation of any duration in individuals 0-95 years old demonstrated that vitamin D reduced the risk for acute respiratory infections overall, with the greatest benefit in those with low 25(OH)D levels $(<10 \mathrm{ng} / \mathrm{mL})$, and those receiving daily or weekly vitamin D supplementation vs. bolus doses $[137,138]$. Effects may be less robust in those 1-5 years old [139], and a dose effect has not been demonstrated [140].

Overall, these data suggest that vitamin D may have an effect in reducing the risk for respiratory infections in children, with more pronounced effects after 5 years of age, and in those that are vitamin $\mathrm{D}$ deficient. This effect may explain the reduced risk of asthma exacerbations in children with vitamin D supplementation (although asthma severity does not appear to improve with vitamin D). The mechanism underlying the effect on respiratory infections needs to be determined, but may involve the impact of vitamin D on inflammatory pathways.

\section{Metabolic Syndrome and Type 2 Diabetes Mellitus}

Although, VDR polymorphisms are unlikely to play a major role in obesity-related phenotypes, as reported in a population of Caucasian adults [141], vitamin D deficiency has been associated with obesity in both pediatric and adult populations. The prevalence of vitamin D deficiency is about $50 \%$ in children with obesity $[142,143]$, and attributable to decreased sun exposure secondary to low 
activity level, poor nutrition with decreased consumption of vitamin D containing foods such as milk, as well as storage in adipose tissue [142]. With the increased prevalence of obesity in children there has also been concern of increased prevalence of type 2 DM (T2D), dyslipidemia and hypertension, the metabolic syndrome [1]. The role vitamin D plays in contributing to these disorders has been of interest given the above association and implications for potential treatment. Exactly which aspects of the metabolic syndrome are associated with vitamin $\mathrm{D}$ deficiency have not been definitively delineated as studies show varied results. Olson et al. found a negative correlation between $25(\mathrm{OH}) \mathrm{D}$ levels and HOMA-IR (homeostasis model assessment of insulin resistance) and weaker but significant inverse correlations with 2-h glucose levels in an oral glucose tolerance test (OGTT). There was no correlation with $\mathrm{HbA1C}$, systolic blood pressure (SBP) or diastolic blood pressure (DBP) [142]. In another study vitamin D deficiency in children with obesity was associated with higher BMI and SBP, and decreased HDL-C [143]. After adjusting for BMI in Native American children, 25(OH)D levels were inversely associated with log transformed fasting 2-h glucose, fasting insulin, HOMA-IR, triglyceride and CRP levels, and SBP and DBP. There was a positive correlation with HDL but no correlation with total or LDL cholesterol [144]. Studies have postulated that adipokines such as adiponectin and resistin may be involved in the pathogenesis of insulin resistance and vitamin D deficiency. a study of 125 children and adolescents with obesity showed a trend toward lower 25(OH)D levels being associated with low adiponectin levels and higher insulin resistance even after adjusting for body mass, though there was no correlation between $25(\mathrm{OH}) \mathrm{D}$ levels and resistin [145].

Conversely, Poomthavorn et al. [146] found no correlation between vitamin D deficiency and abnormal glucose homeostasis in 150 children and adolescents with obesity living in Thailand. In fact, the five children identified with T2D in this study were all vitamin D sufficient. They also found the same degree of vitamin D deficiency in 29 healthy children without obesity [146]. Similarly, Bril et al. found no relationship between lower $25(\mathrm{OH}) \mathrm{D}$ levels and insulin resistance (using an euglycemic insulin clamp), liver fat accumulation or steatohepatitis when adult patients with the latter were matched for BMI and total adiposity with controls [147]. More recently, in a study of 215 children with T1D and 326 children with T2D vs. youth of similar age without diabetes from the 2005-2006 NHANES Survey, the prevalence of vitamin D deficiency or insufficiency did not differ in children with vs. those without diabetes [14]. Additionally, although latitude and the winter months have been associated with a higher risk of hypertension, recent studies suggest that the effect of ultraviolet light on blood pressure is likely mediated via nitric oxide synthesis and not through vitamin D production [148]. Limitations of pediatric studies include the fact that these associative studies often do not include controls matched for measures of adiposity, or use euglycemic clamps to assess insulin resistance. In addition, sample sizes are small and length of studies short. Associations of vitamin D deficiency with worsening insulin resistance or other aspects of the metabolic syndrome are yet to be proven.

Interventional studies in adults and adolescents are described in detail in Table 1 and are summarized here.

Interventional Studies in Adults with Obesity, Prediabetes and T2D: the contribution of vitamin D to the metabolic phenotype of obesity is of interest given implications for treatment. If these associations have a biological basis, repleting vitamin $\mathrm{D}$ should improve the phenotype. How this should be done, to what level of replacement, and the actual efficacy have been the basis of several studies. Vitamin D administration in adults has had mixed results for progression to T2D and cardio-metabolic outcomes. Among short-term studies with small numbers of participants, most have reported no changes in insulin sensitivity [35], insulin secretion [36,37], CRP [36,38], BMI [36], lipids [36,37,39], blood pressure, endothelial function, and arterial stiffness [38] following vitamin D administration, while a few have reported an improvement in insulin sensitivity [36] and blood pressure [39]. Among larger and longer-term studies, a five-year interventional study in 556 adults 25-80 years old at risk for developing T2D, reported no impact of vitamin D administration on progression to T2D, measures of glucose metabolism, serum lipids or blood pressure [40]. a subsequent pooled meta-analysis of 23 RCTs similarly found no effect of vitamin D supplementation in controlling fasting plasma glucose levels, 
improving insulin resistance, or preventing T2D; however, stratified analysis suggested a possible beneficial effect in those without obesity, those with prediabetes, when $25(\mathrm{OH}) \mathrm{D}$ levels were at least $20 \mathrm{ng} / \mathrm{mL}$, and when the supplemental dose was >2000 IUs per day and given without calcium supplementation [41]. Yet, an RCT in adult participants meeting criteria for prediabetes (but not diabetes) reported no difference between groups for onset of diabetes over the study duration [42].

Interventional Studies in Children with Obesity, Prediabetes and T2D: similar to the adult literature, the pediatric literature includes conflicting data regarding effects of vitamin D supplementation [43-52] (Table 1). a retrospective study of vitamin D supplementation in 43 children 3-18 years old with $\mathrm{T} 2 \mathrm{D}$ reported a decrease in BMI-SDS and $\mathrm{HbA} 1 \mathrm{C}$ in those supplemented with vitamin D [46]. A few prospective studies in adolescents with obesity have similarly reported improved HOMA-IR and QUICKI (but not in fasting glucose, HbA1C, CRP, inflammatory markers, blood pressure) [43,45] following vitamin $\mathrm{D}$ administration, and an association of reductions in Apo-B and LDL-C, and increases in HDL with increases in 25(OH)D levels after supplementation [44,49]. However, most prospective interventional studies in children with obesity have failed to demonstrate a beneficial effect of vitamin $D$ administration on fasting lipids, glucose, insulin and CRP values [47,48,50,51], and insulin secretion or sensitivity [52], and dose response studies have similarly not been able to demonstrate an effect of increasing vitamin D doses on fasting glucose, insulin and insulin resistance [48,51] or lipid levels [48].

Overall data indicate that there is an association between obesity and vitamin D deficiency (likely related to sequestration of vitamin $\mathrm{D}$ in adipose depots). However, the biological effect of vitamin $\mathrm{D}$ deficiency on insulin resistance, hypertension, hyperlipidemia and progression to T2D is likely small. Data are conflicting regarding associations of vitamin D deficiency with components of the metabolic syndrome, as well as a treatment effect. Some differences may be attributable to the type of study, sample size, and dose of vitamin D used (Table 1). Larger and longer-term prospective studies are needed to definitively determine causality.

\section{Cancer}

In cell culture studies, $25(\mathrm{OH}) \mathrm{D}$ concentrations of $>30 \mathrm{ng} / \mathrm{mL}$ prevent unregulated cell growth [149-151]. There are very little data for the role of vitamin $\mathrm{D}$ in preventing or ameliorating the course of cancer in children, although low 25(OH)vitamin D levels may contribute to poor bone health in children with hematological and other malignancies [152-154]. Much of the data for the impact of vitamin D in preventing or reducing the morbidity of cancer comes from studies in adults, particularly in the context of breast, colorectal and prostate cancer. This section briefly reviews existing literature for these three kinds of cancer.

In breast cancer cell lines, vitamin D signaling inhibits expression of a tumor progression gene (Id1), and ablation of VDR expression causes increased tumor growth and development of metastases [155]. This pathway is inhibited in murine models of breast cancer associated with vitamin D deficiency, and epidemiological studies in humans suggest associations of vitamin D deficiency and the risk of breast, prostate and colon cancer [156-158]. However, data are conflicting regarding the impact of vitamin D receptor genotype and cancer risk at this time [159]. One study reported that VDR single nucleotide polymorphisms and haplotypes may determine how inflammatory markers change in breast cancer survivors with vitamin D deficiency, following vitamin D supplementation [160].

In general, vitamin D deficiency is associated with increased risk of progression and mortality in breast cancers [161-163]. Of note, these data have been questioned in that meta-analyses indicate that while case control studies suggest a reduction in breast cancer risk in those with higher 25(OH)D levels, this is not evident in prospective studies $[163,164]$. Data suggest that weight and alcohol intake may modify associations between vitamin D intake and breast cancer risk [165]. Of note, the Women's Health Initiative demonstrated no reduction in risk for breast cancer in women receiving $400 \mathrm{IU}$ vitamin $\mathrm{D}_{3}$ and $1000 \mathrm{mg}$ of calcium vs. placebo [166]. However, a decreased risk was noted in postmenopausal women on hormone replacement therapy from daily vitamin D and calcium supplements [167], and another study reported improved breast cancer survival in patients after surgery of invasive breast cancer in de novo vitamin D users [168]. One recent 12-month RCT of 20,000 IUs of vitamin D vs. placebo in 208 
premenopausal women at high risk for breast cancer found no effect of vitamin D supplementation in reducing breast cancer risk (assessed using mammographic density) [169]. Similarly, an RCT of 2000 IUs of vitamin D and omega- 3 fatty acids ( 1 g daily) $(2 \times 2$ factorial design $)$ in women 55 and older and men 50 and older found no effect of vitamin D supplementation in lowering the incidence of invasive cancer compared to placebo [170].

Meta-analyses have reported inverse associations of 25(OH)D levels and vitamin D intake with the incidence and recurrence of colorectal adenoma [171-174]. One meta-analysis suggested a $10 \%-20 \%$ reduction in risk of incidence or recurrence of colorectal adenomas with every $20 \mathrm{ng} / \mathrm{mL}$ increase in 25(OH)D levels [171]. Another meta-analysis suggested a $26 \%$ reduction in risk with every $10 \mathrm{ng} / \mathrm{mL}$ increase in 25(OH)D levels $[175,176]$. However, a large Mendelian randomization study that included 10,725 colorectal cancer cases and 30,794 controls found no evidence for a causal relationship between circulating $25(\mathrm{OH}) \mathrm{D}$ and colorectal cancer risk. These authors suggested that circulating vitamin $\mathrm{D}$ may be a biomarker of colorectal cancer, rather than a causative factor [177]. Thus far, data for a role of VDR polymorphisms in mediating the risk of colorectal adenomas are conflicting, with no associations reported in more recent studies [176,178].

Some studies have suggested that vitamin D with or without calcium supplementation promotes colorectal epithelial cell differentiation, reduces proliferation, and promotes apoptosis, and is thus chemopreventive against colorectal neoplasms [179]. Further, a higher expression of CYP24A1, which reduces local 1,25-D (3) availability and thus its antiproliferative effect, has been demonstrated in colorectal adenocarcinomas, associated with increased expression of the proliferation marker Ki-67 [180]. Despite these data and consistent with the Mendelian randomization study, randomized controlled trials and meta-analyses do not support a role of vitamin D supplementation in preventing these cancers $[161,181,182]$ or relapses [183-185]. Baron et al. disappointingly reported that daily supplementation with vitamin $\mathrm{D}_{3}$ (1000 IU), calcium (1200 mg), or both after removal of colorectal adenomas did not reduce the risk of recurrence over a 3-5 year period [184]. Similarly, Urashima et al. reported no improvement in relapse free survival in patients with digestive tract cancers ( $48 \%$ were colorectal cancers) randomized to 2000 IUs of vitamin D vs. placebo (AMATERASU RCT) [185]. However, in the SUNSHINE trial (a phase 2 RCT in which 139 patients with advanced or metastatic colorectal cancer were randomized to chemotherapy plus high-dose vitamin $\mathrm{D}_{3}$ supplementation (8000 IUs daily for one month followed by 4000 IUs daily vs. chemotherapy plus standard-dose vitamin $\mathrm{D}_{3}(400 \mathrm{IU}$ s daily)) the higher vitamin $\mathrm{D}$ dose was associated with a multivariable hazard ratio of 0.64 for progression-free survival or death that was statistically significant [186].

Sun exposure may delay the onset of prostate cancer [157] while serum 25(OH)D levels of at least $20 \mathrm{ng} / \mathrm{mL}$ appear to reduce the risk for prostate cancer by 50\% [187]. However, data for associations of vitamin D deficiency with incidence of prostate cancer are weaker than those for colon cancer, and data for associations with progression are inconsistent $[161,188]$.

Overall, at this time, data do not support a significant role of vitamin D supplementation in preventing or changing the course of breast, colorectal or prostate cancer.

\section{Conclusions}

In conclusion, vitamin D may have biological effects well beyond the skeleton. While it is important to maintain adequate $25(\mathrm{OH}) \mathrm{D}$ levels for optimal bone health, this may have benefits in a variety of different organ systems. However, interventional studies to prevent or ameliorate disease processes attributable to vitamin $\mathrm{D}$ deficiency in large populations have been disappointing thus far for the most part. More investigation is needed to determine optimal dosing and serum levels to effect positive biological outcomes.

Author Contributions: R.M. and M.M. contributed equally to the concept of this manuscript, the required literature review, and the writing of this manuscript. Both authors approved the submitted version of the manuscript.

Funding: This research was funded in part by K24 HD071843 (Misra).

Conflicts of Interest: The authors have no conflict of interest to disclose relevant to this manuscript. 


\section{References}

1. Misra, M.; Pacaud, D.; Petryk, A.; Collett-Solberg, P.F.; Kappy, M. Vitamin D deficiency in children and its management: Review of current knowledge and recommendations. Pediatrics 2008, 122, 398-417. [CrossRef] [PubMed]

2. Holick, M.F.; Binkley, N.C.; Bischoff-Ferrari, H.A.; Gordon, C.M.; Hanley, D.A.; Heaney, R.P.; Murad, M.H.; Weaver, C.M. Guidelines for preventing and treating vitamin D deficiency and insufficiency revisited. J. Clin. Endocrinol. Metab. 2012, 97, 1153-1158. [CrossRef] [PubMed]

3. Holick, M.F.; Binkley, N.C.; Bischoff-Ferrari, H.A.; Gordon, C.M.; Hanley, D.A.; Heaney, R.P.; Murad, M.H.; Weaver, C.M. Evaluation, treatment, and prevention of vitamin D deficiency: An Endocrine Society clinical practice guideline. J. Clin. Endocrinol. Metab. 2011, 96, 1911-1930. [CrossRef] [PubMed]

4. Ross, A.C.; Manson, J.E.; Abrams, S.A.; Aloia, J.F.; Brannon, P.M.; Clinton, S.K.; Durazo-Arvizu, R.A.; Gallagher, J.C.; Gallo, R.L.; Jones, G.; et al. The 2011 report on dietary reference intakes for calcium and vitamin D from the Institute of Medicine: What clinicians need to know. J. Clin. Endocrinol. Metab. 2011, 96, 53-58. [CrossRef] [PubMed]

5. Guo, J.; Lovegrove, J.A.; Givens, D.I. $25(\mathrm{OH}) \mathrm{D}_{3}$-enriched or fortified foods are more efficient at tackling inadequate vitamin D status than vitamin $\mathrm{D}_{3}$. Proc. Nutr. Soc. 2018, 77, 282-291. [CrossRef] [PubMed]

6. Tsoukas, C.D.; Provvedini, D.M.; Manolagas, S.C. 1,25-dihydroxyvitamin $\mathrm{D}_{3}$ : A novel immunoregulatory hormone. Science 1984, 224, 1438-1440. [CrossRef] [PubMed]

7. Bhalla, A.K.; Amento, E.P.; Clemens, T.L.; Holick, M.F.; Krane, S.M. Specific high-affinity receptors for 1,25-dihydroxyvitamin $\mathrm{D}_{3}$ in human peripheral blood mononuclear cells: Presence in monocytes and induction in T lymphocytes following activation. J. Clin. Endocrinol. Metab. 1983, 57, 1308-1310. [CrossRef] [PubMed]

8. Drozdenko, G.; Scheel, T.; Heine, G.; Baumgrass, R.; Worm, M. Impaired T cell activation and cytokine production by calcitriol-primed human B cells. Clin. Exp. Immunol. 2014, 178, 364-372. [CrossRef] [PubMed]

9. Milliken, S.V.; Wassall, H.; Lewis, B.J.; Logie, J.; Barker, R.N.; Macdonald, H.; Vickers, M.A.; Ormerod, A.D. Effects of ultraviolet light on human serum 25-hydroxyvitamin D and systemic immune function. J. Allergy Clin. Immunol. 2012, 129, 1554-1561. [CrossRef]

10. Al-Zubeidi, H.; Leon-Chi, L.; Newfield, R.S. Low vitamin D level in pediatric patients with new onset type 1 diabetes is common, especially if in ketoacidosis. Pediatr. Diabetes 2016, 17, 592-598. [CrossRef]

11. Savastio, S.; Cadario, F.; Genoni, G.; Bellomo, G.; Bagnati, M.; Secco, G.; Picchi, R.; Giglione, E.; Bona, G. Vitamin D Deficiency and Glycemic Status in Children and Adolescents with Type 1 Diabetes Mellitus. PLoS ONE 2016, 11, e0162554. [CrossRef] [PubMed]

12. Makinen, M.; Mykkanen, J.; Koskinen, M.; Simell, V.; Veijola, R.; Hyoty, H.; Ilonen, J.; Knip, M.; Simell, O.; Toppari, J. Serum 25-Hydroxyvitamin D Concentrations in Children Progressing to Autoimmunity and Clinical Type 1 Diabetes. J. Clin. Endocrinol. Metab. 2016, 101, 723-729. [CrossRef] [PubMed]

13. Granfors, M.; Augustin, H.; Ludvigsson, J.; Brekke, H.K. No association between use of multivitamin supplement containing vitamin D during pregnancy and risk of Type 1 Diabetes in the child. Pediatr. Diabetes 2016, 17, 525-530. [CrossRef] [PubMed]

14. Wood, J.R.; Connor, C.G.; Cheng, P.; Ruedy, K.J.; Tamborlane, W.V.; Klingensmith, G.; Schatz, D.; Gregg, B.; Cengiz, E.; Willi, S.; et al. Vitamin D status in youth with type 1 and type 2 diabetes enrolled in the Pediatric Diabetes Consortium (PDC) is not worse than in youth without diabetes. Pediatr. Diabetes 2016, 17, 584-591. [CrossRef] [PubMed]

15. Bland, R.; Markovic, D.; Hills, C.E.; Hughes, S.V.; Chan, S.L.; Squires, P.E.; Hewison, M. Expression of 25-hydroxyvitamin $\mathrm{D}_{3}$-1alpha-hydroxylase in pancreatic islets. J. Steroid Biochem. Mol. Biol. 2004, 89, 121-125. [CrossRef] [PubMed]

16. Maestro, B.; Davila, N.; Carranza, M.C.; Calle, C. Identification of a Vitamin D response element in the human insulin receptor gene promoter. J. Steroid Biochem. Mol. Biol. 2003, 84, 223-230. [CrossRef]

17. El-Fakhri, N.; McDevitt, H.; Shaikh, M.G.; Halsey, C.; Ahmed, S.F. Vitamin D and its effects on glucose homeostasis, cardiovascular function and immune function. Horm. Res. Paediatr. 2014, 81, 363-378. [CrossRef]

18. Bae, K.N.; Nam, H.K.; Rhie, Y.J.; Song, D.J.; Lee, K.H. Low levels of 25-hydroxyvitamin D in children and adolescents with type 1 diabetes mellitus: A single center experience. Ann. Pediatr. Endocrinol. Metab. 2018, 23, 21-27. [CrossRef] 
19. Federico, G.; Genoni, A.; Puggioni, A.; Saba, A.; Gallo, D.; Randazzo, E.; Salvatoni, A.; Toniolo, A. Vitamin D status, enterovirus infection, and type 1 diabetes in Italian children/adolescents. Pediatr. Diabetes 2018, 19, 923-929. [CrossRef]

20. Cooper, J.D.; Smyth, D.J.; Walker, N.M.; Stevens, H.; Burren, O.S.; Wallace, C.; Greissl, C.; Ramos-Lopez, E.; Hypponen, E.; Dunger, D.B.; et al. Inherited variation in vitamin D genes is associated with predisposition to autoimmune disease type 1 diabetes. Diabetes 2011, 60, 1624-1631. [CrossRef]

21. Sahin, O.A.; Goksen, D.; Ozpinar, A.; Serdar, M.; Onay, H. Association of vitamin D receptor polymorphisms and type 1 diabetes susceptibility in children: A meta-analysis. Endocr. Connect. 2017, 6, 159-171. [CrossRef] [PubMed]

22. Kodama, K.; Zhao, Z.; Toda, K.; Yip, L.; Fuhlbrigge, R.; Miao, D.; Fathman, C.G.; Yamada, S.; Butte, A.J.; Yu, L. Expression-Based Genome-Wide Association Study Links Vitamin D-Binding Protein with Autoantigenicity in Type 1 Diabetes. Diabetes 2016, 65, 1341-1349. [CrossRef] [PubMed]

23. Sorensen, I.M.; Joner, G.; Jenum, P.A.; Eskild, A.; Brunborg, C.; Torjesen, P.A.; Stene, L.C. Vitamin D-binding protein and 25-hydroxyvitamin D during pregnancy in mothers whose children later developed type 1 diabetes. Diabetes Metab. Res. Rev. 2016, 32, 883-890. [CrossRef] [PubMed]

24. Tapia, G.; Marild, K.; Dahl, S.R.; Lund-Blix, N.A.; Viken, M.K.; Lie, B.A.; Njolstad, P.R.; Joner, G.; Skrivarhaug, T.; Cohen, A.S.; et al. Maternal and Newborn Vitamin D-Binding Protein, Vitamin D Levels, Vitamin D Receptor Genotype, and Childhood Type 1 Diabetes. Diabetes Care 2019, 42, 553-559. [CrossRef] [PubMed]

25. Gabbay, M.A.; Sato, M.N.; Finazzo, C.; Duarte, A.J.; Dib, S.A. Effect of cholecalciferol as adjunctive therapy with insulin on protective immunologic profile and decline of residual beta-cell function in new-onset type 1 diabetes mellitus. Arch. Pediatr. Adolesc. Med. 2012, 166, 601-607. [CrossRef]

26. Treiber, G.; Prietl, B.; Frohlich-Reiterer, E.; Lechner, E.; Ribitsch, A.; Fritsch, M.; Rami-Merhar, B.; Steigleder-Schweiger, C.; Graninger, W.; Borkenstein, M.; et al. Cholecalciferol supplementation improves suppressive capacity of regulatory T-cells in young patients with new-onset type 1 diabetes mellitusA randomized clinical trial. Clin. Immunol. 2015, 161, 217-224. [CrossRef] [PubMed]

27. Zipitis, C.S.; Akobeng, A.K. Vitamin D supplementation in early childhood and risk of type 1 diabetes: A systematic review and meta-analysis. Arch. Dis. Child. 2008, 93, 512-517. [CrossRef] [PubMed]

28. Zipitis, C.S.; Mughal, Z.M.; Clayton, P.E. Assessing the population impact of low rates of vitamin D supplementation on type 1 diabetes using a new statistical method. JRSM Open 2016, 7. [CrossRef] [PubMed]

29. Ataie-Jafari, A.; Loke, S.C.; Rahmat, A.B.; Larijani, B.; Abbasi, F.; Leow, M.K.; Yassin, Z. a randomized placebo-controlled trial of alphacalcidol on the preservation of beta cell function in children with recent onset type 1 diabetes. Clin. Nutr. 2013, 32, 911-917. [CrossRef]

30. Deda, L.; Yeshayahu, Y.; Sud, S.; Cuerden, M.; Cherney, D.Z.; Sochett, E.B.; Mahmud, F.H. Improvements in peripheral vascular function with vitamin $\mathrm{D}$ treatment in deficient adolescents with type 1 diabetes. Pediatr. Diabetes 2018, 19, 457-463. [CrossRef] [PubMed]

31. Silvis, K.; Aronsson, C.A.; Liu, X.; Uusitalo, U.; Yang, J.; Tamura, R.; Lernmark, A.; Rewers, M.; Hagopian, W.; She, J.X.; et al. Maternal dietary supplement use and development of islet autoimmunity in the offspring: TEDDY study. Pediatr. Diabetes 2019, 20, 86-92. [CrossRef] [PubMed]

32. Bizzarri, C.; Pitocco, D.; Napoli, N.; Di Stasio, E.; Maggi, D.; Manfrini, S.; Suraci, C.; Cavallo, M.G.; Cappa, M.; Ghirlanda, G.; et al. No protective effect of calcitriol on beta-cell function in recent-onset type 1 diabetes: The IMDIAB XIII trial. Diabetes Care 2010, 33, 1962-1963. [CrossRef] [PubMed]

33. Perchard, R.; Magee, L.; Whatmore, A.; Ivison, F.; Murray, P.; Stevens, A.; Mughal, M.Z.; Ehtisham, S.; Campbell, J.; Ainsworth, S.; et al. a pilot interventional study to evaluate the impact of cholecalciferol treatment on HbA1c in type 1 diabetes (T1D). Endocr. Connect. 2017, 6, 225-231. [CrossRef] [PubMed]

34. Sharma, S.; Biswal, N.; Bethou, A.; Rajappa, M.; Kumar, S.; Vinayagam, V. Does Vitamin D Supplementation Improve Glycaemic Control in Children with Type 1 Diabetes Mellitus?-A Randomized Controlled Trial. J. Clin. Diagn. Res. 2017, 11, SC15. [CrossRef] [PubMed]

35. Tai, K.; Need, A.G.; Horowitz, M.; Chapman, I.M. Glucose tolerance and vitamin D: Effects of treating vitamin D deficiency. Nutrition 2008, 24, 950-956. [CrossRef] [PubMed]

36. Von Hurst, P.R.; Stonehouse, W.; Coad, J. Vitamin D supplementation reduces insulin resistance in South Asian women living in New Zealand who are insulin resistant and vitamin D deficient-A randomised, placebo-controlled trial. Br. J. Nutr. 2010, 103, 549-555. [CrossRef] [PubMed] 
37. Grimnes, G.; Figenschau, Y.; Almas, B.; Jorde, R. Vitamin D insulin secretion, sensitivity, and lipids: Results from a case-control study and a randomized controlled trial using hyperglycemic clamp technique. Diabetes 2011, 60, 2748-2757. [CrossRef]

38. Gepner, A.D.; Ramamurthy, R.; Krueger, D.C.; Korcarz, C.E.; Binkley, N.; Stein, J.H. a prospective randomized controlled trial of the effects of vitamin D supplementation on cardiovascular disease risk. PLoS ONE 2012, 7, e36617. [CrossRef]

39. Toxqui, L.; Blanco-Rojo, R.; Wright, I.; Perez-Granados, A.M.; Vaquero, M.P. Changes in blood pressure and lipid levels in young women consuming a vitamin D-fortified skimmed milk: A randomised controlled trial. Nutrients 2013, 5, 4966-4977. [CrossRef]

40. Jorde, R.; Sollid, S.T.; Svartberg, J.; Schirmer, H.; Joakimsen, R.M.; Njolstad, I.; Fuskevag, O.M.; Figenschau, Y.; Hutchinson, M.Y. Vitamin D 20,000 IU per Week for Five Years Does Not Prevent Progression from Prediabetes to Diabetes. J. Clin. Endocrinol. Metab. 2016, 101, 1647-1655. [CrossRef]

41. He, S.; Yu, S.; Zhou, Z.; Wang, C.; Wu, Y.; Li, W. Effect of vitamin D supplementation on fasting plasma glucose, insulin resistance and prevention of type 2 diabetes mellitus in non-diabetics: A systematic review and meta-analysis. Biomed. Rep. 2018, 8, 475-484. [CrossRef] [PubMed]

42. Pittas, A.G.; Dawson-Hughes, B.; Sheehan, P.; Ware, J.H.; Knowler, W.C.; Aroda, V.R.; Brodsky, I.; Ceglia, L.; Chadha, C.; Chatterjee, R.; et al. Vitamin D Supplementation and Prevention of Type 2 Diabetes. N. Engl. J. Med. 2019. [CrossRef] [PubMed]

43. Belenchia, A.M.; Tosh, A.K.; Hillman, L.S.; Peterson, C.A. Correcting vitamin D insufficiency improves insulin sensitivity in obese adolescents: A randomized controlled trial. Am. J. Clin. Nutr. 2013, 97, 774-781. [CrossRef] [PubMed]

44. Hirschler, V.; Maccallini, G.; Sanchez, M.; Claudio, G.; Molinari, C.; Figueroa, M.; Arnada, C.; Hidalgo, M. Improvement of Apolipoprotein B in Argentine Indigenous School Children after Vitamin D Supplementation. Cardiovasc. Hematol. Agents Med. Chem. 2015, 13, 137-145. [CrossRef] [PubMed]

45. Kelishadi, R.; Salek, S.; Salek, M.; Hashemipour, M.; Movahedian, M. Effects of vitamin D supplementation on insulin resistance and cardiometabolic risk factors in children with metabolic syndrome: A triple-masked controlled trial. J. Pediatr. 2014, 90, 28-34. [CrossRef] [PubMed]

46. Nwosu, B.U.; Maranda, L. The effects of vitamin D supplementation on hepatic dysfunction, vitamin D status, and glycemic control in children and adolescents with vitamin D deficiency and either type 1 or type 2 diabetes mellitus. PLoS ONE 2014, 9, e99646. [CrossRef] [PubMed]

47. Nader, N.S.; Aguirre Castaneda, R.; Wallace, J.; Singh, R.; Weaver, A.; Kumar, S. Effect of vitamin $\mathrm{D}_{3}$ supplementation on serum $25(\mathrm{OH}) \mathrm{D}$, lipids and markers of insulin resistance in obese adolescents: A prospective, randomized, placebo-controlled pilot trial. Horm. Res. Paediatr. 2014, 82, 107-112. [CrossRef] [PubMed]

48. Javed, A.; Vella, A.; Balagopal, P.B.; Fischer, P.R.; Weaver, A.L.; Piccinini, F.; Dalla Man, C.; Cobelli, C.; Giesler, P.D.; Laugen, J.M.; et al. Cholecalciferol supplementation does not influence beta-cell function and insulin action in obese adolescents: A prospective double-blind randomized trial. J. Nutr. 2015, 145, 284-290. [CrossRef] [PubMed]

49. Hirschler, V.; Maccallini, G.; Sanchez, M.S.; Castano, L.; Molinari, C. Improvement in high-density lipoprotein cholesterol levels in argentine Indian school children after vitamin D supplementation. Horm. Res. Paediatr. 2013, 80, 335-342. [CrossRef] [PubMed]

50. Javed, A.; Kullo, I.J.; Balagopal, P.B.; Kumar, S. Effect of vitamin $\mathrm{D}_{3}$ treatment on endothelial function in obese adolescents. Pediatr. Obes. 2016, 11, 279-284. [CrossRef] [PubMed]

51. Ferira, A.J.; Laing, E.M.; Hausman, D.B.; Hall, D.B.; McCabe, G.P.; Martin, B.R.; Hill Gallant, K.M.; Warden, S.J.; Weaver, C.M.; Peacock, M.; et al. Vitamin D Supplementation Does Not Impact Insulin Resistance in Black and White Children. J. Clin. Endocrinol. Metab. 2016, 101, 1710-1718. [CrossRef] [PubMed]

52. Sethuraman, U.; Zidan, M.A.; Hanks, L.; Bagheri, M.; Ashraf, A. Impact of vitamin D treatment on 25 hydroxy vitamin D levels and insulin homeostasis in obese African American adolescents in a randomized trial. J. Clin. Transl. Endocrinol. 2018, 12, 13-19. [CrossRef] [PubMed]

53. Hernan, M.A.; Olek, M.J.; Ascherio, A. Geographic variation of MS incidence in two prospective studies of US women. Neurology 1999, 53, 1711-1718. [CrossRef] [PubMed] 
54. Dalmay, F.; Bhalla, D.; Nicoletti, A.; Cabrera-Gomez, J.A.; Cabre, P.; Ruiz, F.; Druet-Cabanac, M.; Dumas, M.; Preux, P.M. Multiple sclerosis and solar exposure before the age of 15 years: Case-control study in Cuba, Martinique and Sicily. Mult. Scler. 2010, 16, 899-908. [CrossRef] [PubMed]

55. Islam, T.; Gauderman, W.J.; Cozen, W.; Mack, T.M. Childhood sun exposure influences risk of multiple sclerosis in monozygotic twins. Neurology 2007, 69, 381-388. [CrossRef] [PubMed]

56. Dwyer, T.; van der Mei, I.; Ponsonby, A.L.; Taylor, B.V.; Stankovich, J.; McKay, J.D.; Thomson, R.J.; Polanowski, A.M.; Dickinson, J.L. Melanocortin 1 receptor genotype, past environmental sun exposure, and risk of multiple sclerosis. Neurology 2008, 71, 583-589. [CrossRef] [PubMed]

57. van der Mei, I.A.; Ponsonby, A.L.; Dwyer, T.; Blizzard, L.; Simmons, R.; Taylor, B.V.; Butzkueven, H.; Kilpatrick, T. Past exposure to sun, skin phenotype, and risk of multiple sclerosis: Case-control study. BMJ 2003, 327, 316. [CrossRef]

58. Alonso, A.; Cook, S.D.; Maghzi, A.H.; Divani, A.A. a case-control study of risk factors for multiple sclerosis in Iran. Mult. Scler. 2011, 17, 550-555. [CrossRef]

59. Baarnhielm, M.; Hedstrom, A.K.; Kockum, I.; Sundqvist, E.; Gustafsson, S.A.; Hillert, J.; Olsson, T.; Alfredsson, L. Sunlight is associated with decreased multiple sclerosis risk: No interaction with human leukocyte antigen-DRB1*15. Eur. J. Neurol. 2012, 19, 955-962. [CrossRef]

60. Munger, K.L.; Zhang, S.M.; O’Reilly, E.; Hernan, M.A.; Olek, M.J.; Willett, W.C.; Ascherio, A. Vitamin D intake and incidence of multiple sclerosis. Neurology 2004, 62, 60-65. [CrossRef]

61. Munger, K.L.; Levin, L.I.; Hollis, B.W.; Howard, N.S.; Ascherio, A. Serum 25-hydroxyvitamin D levels and risk of multiple sclerosis. JAMA 2006, 296, 2832-2838. [CrossRef]

62. Kragt, J.; van Amerongen, B.; Killestein, J.; Dijkstra, C.; Uitdehaag, B.; Polman, C.; Lips, P. Higher levels of 25-hydroxyvitamin D are associated with a lower incidence of multiple sclerosis only in women. Mult. Scler. 2009, 15, 9-15. [CrossRef]

63. Shaygannejad, V.; Golabchi, K.; Haghighi, S.; Dehghan, H.; Moshayedi, A. a Comparative Study of 25 $(\mathrm{OH})$ Vitamin D Serum Levels in Patients with Multiple Sclerosis and Control Group in Isfahan, Iran. Int. J. Prev. Med. 2010, 1, 195-201.

64. Soilu-Hanninen, M.; Airas, L.; Mononen, I.; Heikkila, A.; Viljanen, M.; Hanninen, A. 25-Hydroxyvitamin D levels in serum at the onset of multiple sclerosis. Mult. Scler. 2005, 11, 266-271. [CrossRef]

65. Graves, J.S.; Barcellos, L.F.; Krupp, L.; Belman, A.; Shao, X.; Quach, H.; Hart, J.; Chitnis, T.; Weinstock-Guttman, B.; Aaen, G.; et al. Vitamin D genes influence MS relapses in children. Mult. Scler. 2019. [CrossRef]

66. Willer, C.J.; Dyment, D.A.; Sadovnick, A.D.; Rothwell, P.M.; Murray, T.J.; Ebers, G.C. Timing of birth and risk of multiple sclerosis: Population based study. BMJ 2005, 330, 120. [CrossRef]

67. Staples, J.; Ponsonby, A.L.; Lim, L. Low maternal exposure to ultraviolet radiation in pregnancy, month of birth, and risk of multiple sclerosis in offspring: Longitudinal analysis. BMJ 2010, 340, c1640.

68. Torkildsen, O.; Grytten, N.; Aarseth, J.; Myhr, K.M.; Kampman, M.T. Month of birth as a risk factor for multiple sclerosis: An update. Acta Neurol. Scand. Suppl. 2012, 126, 58-62. [CrossRef]

69. Disanto, G.; Morahan, J.M.; Ramagopalan, S.V. Multiple sclerosis: Risk factors and their interactions. CNS Neurol. Disord. Drug Targets 2012, 11, 545-555. [CrossRef]

70. Mirzaei, F.; Michels, K.B.; Munger, K.; O’Reilly, E.; Chitnis, T.; Forman, M.R.; Giovannucci, E.; Rosner, B.; Ascherio, A. Gestational vitamin D and the risk of multiple sclerosis in offspring. Ann. Neurol. 2011, 70, 30-40. [CrossRef]

71. McKay, K.A.; Jahanfar, S.; Duggan, T.; Tkachuk, S.; Tremlett, H. Factors associated with onset, relapses or progression in multiple sclerosis: A systematic review. Neurotoxicology 2016, 61, 189-212. [CrossRef]

72. McLaughlin, L.; Clarke, L.; Khalilidehkordi, E.; Butzkueven, H.; Taylor, B.; Broadley, S.A. Vitamin D for the treatment of multiple sclerosis: A meta-analysis. J. Neurol. 2018, 265, 2893-2905. [CrossRef]

73. Soilu-Hanninen, M.; Aivo, J.; Lindstrom, B.M.; Elovaara, I.; Sumelahti, M.L.; Farkkila, M.; Tienari, P.; Atula, S.; Sarasoja, T.; Herrala, L.; et al. a randomised, double blind, placebo controlled trial with vitamin $\mathrm{D}_{3}$ as an add on treatment to interferon beta-1b in patients with multiple sclerosis. J. Neurol. Neurosurg. Psychiatry 2012, 83, 565-571. [CrossRef]

74. Lee, Y.H.; Bae, S.C. Vitamin D level in rheumatoid arthritis and its correlation with the disease activity: A meta-analysis. Clin. Exp. Rheumatol. 2016, 34, 827-833.

75. Son, K.M.; Song, S.H.; Lim, S.K.; Seo, Y.I.; Kim, H.A. Characteristics of patients with rheumatoid arthritis in clinical remission: The many aspects of DAS28 remission. Clin. Exp. Rheumatol. 2012, 30, 947-950. 
76. Song, G.G.; Bae, S.C.; Lee, Y.H. Association between vitamin D intake and the risk of rheumatoid arthritis: A meta-analysis. Clin. Rheumatol. 2012, 31, 1733-1739. [CrossRef]

77. Lin, J.; Liu, J.; Davies, M.L.; Chen, W. Serum Vitamin D Level and Rheumatoid Arthritis Disease Activity: Review and Meta-Analysis. PLoS ONE 2016, 11, e0146351. [CrossRef]

78. Wang, Y.; Zhang, F.; Wang, S.; Shang, X.; Luo, S.; Zhou, H.; Shi, H.; Cai, L. Serum Vitamin D Level is Inversely Associated with Anti-Cyclic Citrullinated Peptide Antibody Level and Disease Activity in Rheumatoid Arthritis Patients. Arch. Rheumatol. 2016, 31, 64-70. [CrossRef]

79. Zakeri, Z.; Sandoughi, M.; Mashhadi, M.A.; Raeesi, V.; Shahbakhsh, S. Serum vitamin D level and disease activity in patients with recent onset rheumatoid arthritis. Int. J. Rheum. Dis. 2016, 19, 343-347. [CrossRef]

80. Tizaoui, K.; Hamzaoui, K. Association between VDR polymorphisms and rheumatoid arthritis disease: Systematic review and updated meta-analysis of case-control studies. Immunobiology 2015, 220, 807-816. [CrossRef]

81. Song, G.G.; Bae, S.C.; Lee, Y.H. Vitamin D receptor FokI, BsmI, and TaqI polymorphisms and susceptibility to rheumatoid arthritis: A meta-analysis. Z. Rheumatol. 2016, 75, 322-329. [CrossRef]

82. Merlino, L.A.; Curtis, J.; Mikuls, T.R.; Cerhan, J.R.; Criswell, L.A.; Saag, K.G. Vitamin D intake is inversely associated with rheumatoid arthritis: Results from the Iowa Women's Health Study. Arthritis Rheum. 2004, 50, 72-77. [CrossRef]

83. Chandrashekara, S.; Patted, A. Role of vitamin D supplementation in improving disease activity in rheumatoid arthritis: An exploratory study. Int. J. Rheum. Dis. 2015, 20, 825-831. [CrossRef]

84. Franco, A.S.; Freitas, T.Q.; Bernardo, W.M.; Pereira, R.M.R. Vitamin D supplementation and disease activity in patients with immune-mediated rheumatic diseases: A systematic review and meta-analysis. Medicine 2017, 96, e7024. [CrossRef] [PubMed]

85. Gardner, D.H.; Jeffery, L.E.; Soskic, B.; Briggs, Z.; Hou, T.Z.; Raza, K.; Sansom, D.M. 1,25(OH) ${ }_{2} \mathrm{D}_{3}$ Promotes the Efficacy of CD28 Costimulation Blockade by Abatacept. J. Immunol. 2015, 195, 2657-2665. [CrossRef]

86. Amital, H.; Szekanecz, Z.; Szucs, G.; Danko, K.; Nagy, E.; Csepany, T.; Kiss, E.; Rovensky, J.; Tuchynova, A.; Kozakova, D.; et al. Serum concentrations of $25-\mathrm{OH}$ vitamin D in patients with systemic lupus erythematosus (SLE) are inversely related to disease activity: Is it time to routinely supplement patients with SLE with vitamin D? Ann. Rheum. Dis. 2010, 69, 1155-1157. [CrossRef]

87. Robinson, A.B.; Thierry-Palmer, M.; Gibson, K.L.; Rabinovich, C.E. Disease activity, proteinuria, and vitamin D status in children with systemic lupus erythematosus and juvenile dermatomyositis. J. Pediatr. 2012, 160, 297-302. [CrossRef]

88. Wright, T.B.; Shults, J.; Leonard, M.B.; Zemel, B.S.; Burnham, J.M. Hypovitaminosis D is associated with greater body mass index and disease activity in pediatric systemic lupus erythematosus. J. Pediatr. 2009, 155, 260-265. [CrossRef]

89. Kamen, D.; Aranow, C. Vitamin D in systemic lupus erythematosus. Curr. Opin. Rheumatol. 2008, 20, 532-537. [CrossRef]

90. AlSaleem, A.; AlE'ed, A.; AlSaghier, A.; Al-Mayouf, S.M. Vitamin D status in children with systemic lupus erythematosus and its association with clinical and laboratory parameters. Clin. Rheumatol. 2015, 34, 81-84. [CrossRef]

91. Borba, V.Z.; Vieira, J.G.; Kasamatsu, T.; Radominski, S.C.; Sato, E.I.; Lazaretti-Castro, M. Vitamin D deficiency in patients with active systemic lupus erythematosus. Osteoporos. Int. 2009, 20, 427-433. [CrossRef] [PubMed]

92. Schneider, L.; Dos Santos, A.S.; Santos, M.; da Silva Chakr, R.M.; Monticielo, O.A. Vitamin D and systemic lupus erythematosus: State of the art. Clin. Rheumatol. 2014, 33, 1033-1038. [CrossRef] [PubMed]

93. Lima, G.L.; Paupitz, J.; Aikawa, N.E.; Takayama, L.; Bonfa, E.; Pereira, R.M. Vitamin D Supplementation in Adolescents and Young Adults with Juvenile Systemic Lupus Erythematosus for Improvement in Disease Activity and Fatigue Scores: A Randomized, Double-Blind, Placebo-Controlled Trial. Arthritis Care Res. 2016, 68, 91-98. [CrossRef] [PubMed]

94. Abou-Raya, A.; Abou-Raya, S.; Helmii, M. The effect of vitamin D supplementation on inflammatory and hemostatic markers and disease activity in patients with systemic lupus erythematosus: A randomized placebo-controlled trial. J. Rheumatol. 2013, 40, 265-272. [CrossRef] [PubMed] 
95. Terrier, B.; Derian, N.; Schoindre, Y.; Chaara, W.; Geri, G.; Zahr, N.; Mariampillai, K.; Rosenzwajg, M.; Carpentier, W.; Musset, L.; et al. Restoration of regulatory and effector T cell balance and B cell homeostasis in systemic lupus erythematosus patients through vitamin D supplementation. Arthritis Res. Ther. 2012, 14, R221. [CrossRef] [PubMed]

96. Shoenfeld, Y.; Giacomelli, R.; Azrielant, S.; Berardicurti, O.; Reynolds, J.A.; Bruce, I.N. Vitamin D and systemic lupus erythematosus-The hype and the hope. Autoimmun. Rev. 2018, 17, 19-23. [CrossRef] [PubMed]

97. Smith, E.L.; Walworth, N.C.; Holick, M.F. Effect of 1 alpha,25-dihydroxyvitamin $\mathrm{D}_{3}$ on the morphologic and biochemical differentiation of cultured human epidermal keratinocytes grown in serum-free conditions. J. Investig. Dermatol. 1986, 86, 709-714. [CrossRef] [PubMed]

98. Smith, E.L.; Pincus, S.H.; Donovan, L.; Holick, M.F. a novel approach for the evaluation and treatment of psoriasis. Oral or topical use of 1,25-dihydroxyvitamin $\mathrm{D}_{3}$ can be a safe and effective therapy for psoriasis. J. Am. Acad. Dermatol. 1988, 19, 516-528. [CrossRef]

99. Stefanic, M.; Rucevic, I.; Barisic-Drusko, V. Meta-analysis of vitamin D receptor polymorphisms and psoriasis risk. Int. J. Dermatol. 2013, 52, 705-710. [CrossRef]

100. Lee, Y.H. Vitamin D receptor ApaI, TaqI, BsmI, and FokI polymorphisms and psoriasis susceptibility: An updated meta-analysis. Clin. Exp. Dermatol. 2019, 44, 498-505. [CrossRef]

101. Saleky, S.; Bulur, I.; Saracoglu, Z.N. Narrowband UVB treatment increases serum 25-hydroxyvitamin D levels in patients with chronic plaque psoriasis. Cutis 2017, 99, 431-435. [PubMed]

102. Gupta, A.; Arora, T.C.; Jindal, A.; Bhadoria, A.S. Efficacy of narrowband ultraviolet B phototherapy and levels of serum vitamin $\mathrm{D}_{3}$ in psoriasis: A prospective study. Indian Dermatol. Online J. 2016, 7, 87-92. [CrossRef] [PubMed]

103. Disphanurat, W.; Viarasilpa, W.; Chakkavittumrong, P.; Pongcharoen, P. The Clinical Effect of Oral Vitamin $D_{2}$ Supplementation on Psoriasis: A Double-Blind, Randomized, Placebo-Controlled Study. Dermatol. Res. Pract. 2019, 2019. [CrossRef] [PubMed]

104. Del Rosso, J.Q.; Kircik, L.H. The Effect of Calcipotriene-Betamethasone Dipropionate Aerosol Foam versus Vehicle on Target Lesions in Moderate Severity Plaque Psoriasis: Focus on Elbows and Knees. J. Drugs Dermatol. 2019, 18, 358-361. [PubMed]

105. German, B.; Wei, R.; Hener, P.; Martins, C.; Ye, T.; Gottwick, C.; Yang, J.; Seneschal, J.; Boniface, K.; Li, M. Disrupting the IL-36 and IL-23/IL-17 loop underlies the efficacy of calcipotriol and corticosteroid therapy for psoriasis. JCI Insight. 2019, 4. [CrossRef] [PubMed]

106. Hau, C.S.; Shimizu, T.; Tada, Y.; Kamata, M.; Takeoka, S.; Shibata, S.; Mitsui, A.; Asano, Y.; Sugaya, M.; Kadono, T.; et al. The vitamin $\mathrm{D}_{3}$ analog, maxacalcitol, reduces psoriasiform skin inflammation by inducing regulatory T cells and downregulating IL-23 and IL-17 production. J. Dermatol. Sci. 2018, 92, 117-126. [CrossRef] [PubMed]

107. Cantorna, M.T.; Munsick, C.; Bemiss, C.; Mahon, B.D. 1,25-Dihydroxycholecalciferol prevents and ameliorates symptoms of experimental murine inflammatory bowel disease. J. Nutr. 2000, 130, 2648-2652. [CrossRef]

108. Bouillon, R.; Carmeliet, G.; Verlinden, L.; van Etten, E.; Verstuyf, A.; Luderer, H.F.; Lieben, L.; Mathieu, C.; Demay, M. Vitamin D and human health: Lessons from vitamin D receptor null mice. Endocr. Rev. 2008, 29, 726-776. [CrossRef]

109. Simmons, J.D.; Mullighan, C.; Welsh, K.I.; Jewell, D.P. Vitamin D receptor gene polymorphism: Association with Crohn's disease susceptibility. Gut 2000, 47, 211-214. [CrossRef]

110. Wang, L.; Wang, Z.T.; Hu, J.J.; Fan, R.; Zhou, J.; Zhong, J. Polymorphisms of the vitamin D receptor gene and the risk of inflammatory bowel disease: A meta-analysis. Genet. Mol. Res. 2014, 13, 2598-2610. [CrossRef]

111. Peyrin-Biroulet, L.; Oussalah, A.; Boucekkine, T.; Bigard, M.A. TNF antagonists in the treatment of inflammatory bowel disease: Results of a survey of gastroenterologists in the French region of Lorraine. Gastroenterol. Clin. Biol. 2009, 33, 23-30. [CrossRef] [PubMed]

112. Janssen, C.E.; Globig, A.M.; Busse Grawitz, A.; Bettinger, D.; Hasselblatt, P. Seasonal variability of vitamin D status in patients with inflammatory bowel disease-A retrospective cohort study. PLoS ONE 2019, 14, e0217238. [CrossRef] [PubMed]

113. Lu, C.; Yang, J.; Yu, W.; Li, D.; Xiang, Z.; Lin, Y.; Yu, C. Association between 25(OH)D Level, Ultraviolet Exposure, Geographical Location, and Inflammatory Bowel Disease Activity: A Systematic Review and Meta-Analysis. PLoS ONE 2015, 10, e0132036. [CrossRef] [PubMed] 
114. Del Pinto, R.; Pietropaoli, D.; Chandar, A.K.; Ferri, C.; Cominelli, F. Association between Inflammatory Bowel Disease and Vitamin D Deficiency: A Systematic Review and Meta-analysis. Inflamm. Bowel Dis. 2015, 21, 2708-2717. [CrossRef] [PubMed]

115. Pappa, H.M.; Mitchell, P.D.; Jiang, H.; Kassiff, S.; Filip-Dhima, R.; DiFabio, D.; Quinn, N.; Lawton, R.C.; Bronzwaer, M.E.; Koenen, M.; et al. Maintenance of optimal vitamin D status in children and adolescents with inflammatory bowel disease: A randomized clinical trial comparing two regimens. J. Clin. Endocrinol. Metab. 2014, 99, 3408-3417. [CrossRef]

116. Schardey, J.; Globig, A.M.; Janssen, C.; Hofmann, M.; Manegold, P.; Thimme, R.; Hasselblatt, P. Vitamin D inhibits pro-inflammatory $\mathrm{T}$ cell function in patients with inflammatory bowel disease. J. Crohn's Colitis 2019. [CrossRef] [PubMed]

117. Guo, H.; Zheng, Y.; Cai, X.; Yang, H.; Zhang, Y.; Hao, L.; Jin, Y.; Yang, G. Correlation between serum vitamin D status and immunological changes in children affected by gastrointestinal food allergy. Allergol. Immunopathol. 2018, 46, 39-44. [CrossRef]

118. Hennessy, A.; Hourihane, J.O.; Malvisi, L.; Irvine, A.D.; Kenny, L.C.; Murray, D.M.; Kiely, M.E. Antenatal vitamin D exposure and childhood eczema, food allergy, asthma and allergic rhinitis at 2 and 5 years of age in the atopic disease-specific Cork BASELINE Birth Cohort Study. Allergy 2018, 73, 2182-2191. [CrossRef]

119. Molloy, J.; Koplin, J.J.; Allen, K.J.; Tang, M.L.K.; Collier, F.; Carlin, J.B.; Saffery, R.; Burgner, D.; Ranganathan, S.; Dwyer, T.; et al. Vitamin D insufficiency in the first 6 months of infancy and challenge-proven IgE-mediated food allergy at 1 year of age: A case-cohort study. Allergy 2017, 72, 1222-1231. [CrossRef]

120. Willits, E.K.; Wang, Z.; Jin, J.; Patel, B.; Motosue, M.; Bhagia, A.; Almasri, J.; Erwin, P.J.; Kumar, S.; Joshi, A.Y. Vitamin D and food allergies in children: A systematic review and meta-analysis. Allergy Asthma Proc. 2017, 38, 21-28. [CrossRef]

121. Peroni, D.G.; Boner, A.L. Food allergy: The perspectives of prevention using vitamin, D. Curr. Opin. Allergy Clin. Immunol. 2013, 13, 287-292. [CrossRef] [PubMed]

122. Rosendahl, J.; Pelkonen, A.S.; Helve, O.; Hauta-Alus, H.; Holmlund-Suila, E.; Valkama, S.; Enlund-Cerullo, M.; Viljakainen, H.; Hytinantti, T.; Makitie, O.; et al. High-Dose Vitamin D Supplementation Does Not Prevent Allergic Sensitization of Infants. J. Pediatr. 2019, 209, 139-145.e1. [CrossRef] [PubMed]

123. Suneetha, P.V.; Sarin, S.K.; Goyal, A.; Kumar, G.T.; Shukla, D.K.; Hissar, S. Association between vitamin D receptor, CCR5, TNF-alpha and TNF-beta gene polymorphisms and HBV infection and severity of liver disease. J. Hepatol. 2006, 44, 856-863. [CrossRef] [PubMed]

124. Nosratabadi, R.; Arababadi, M.K.; Salehabad, V.A.; Shamsizadeh, A.; Mahmoodi, M.; Sayadi, A.R.; Kennedy, D. Polymorphisms within exon 9 but not intron 8 of the vitamin D receptor are associated with the nephropathic complication of type-2 diabetes. Int. J. Immunogenet. 2010, 37, 493-497. [CrossRef] [PubMed]

125. Hu, Y.C.; Wang, W.W.; Jiang, W.Y.; Li, C.Q.; Guo, J.C.; Xun, Y.H. Low vitamin D levels are associated with high viral loads in patients with chronic hepatitis B: A systematic review and meta-analysis. BMC Gastroenterol. 2019, 19, 84. [CrossRef] [PubMed]

126. Petta, S.; Camma, C.; Scazzone, C.; Tripodo, C.; Di Marco, V.; Bono, A.; Cabibi, D.; Licata, G.; Porcasi, R.; Marchesini, G.; et al. Low vitamin D serum level is related to severe fibrosis and low responsiveness to interferon-based therapy in genotype 1 chronic hepatitis, C. Hepatology 2010, 51, 1158-1167. [CrossRef]

127. Barooah, P.; Saikia, S.; Bharadwaj, R.; Sarmah, P.; Bhattacharyya, M.; Goswami, B.; Medhi, S. Role of VDR, GC, and CYP2R1 Polymorphisms in the Development of Hepatocellular Carcinoma in Hepatitis C Virus-Infected Patients. Genet. Test. Mol. Biomark. 2019, 23, 325-331. [CrossRef]

128. Murayama, A.; Saitoh, H.; Takeuchi, A.; Yamada, N.; Matsumura, T.; Shiina, M.; Muramatsu, M.; Wakita, T.; Imawari, M.; Kato, T. Vitamin D derivatives inhibit hepatitis $C$ virus production through the suppression of apolipoprotein. Antivir. Res. 2018, 160, 55-63. [CrossRef]

129. Bitetto, D.; Fabris, C.; Fornasiere, E.; Pipan, C.; Fumolo, E.; Cussigh, A.; Bignulin, S.; Cmet, S.; Fontanini, E.; Falleti, E.; et al. Vitamin D supplementation improves response to antiviral treatment for recurrent hepatitis C. Transpl. Int. 2011, 24, 43-50. [CrossRef]

130. Komolmit, P.; Kimtrakool, S.; Suksawatamnuay, S.; Thanapirom, K.; Chattrasophon, K.; Thaimai, P.; Chirathaworn, C.; Poovorawan, Y. Vitamin D supplementation improves serum markers associated with hepatic fibrogenesis in chronic hepatitis C patients: A randomized, double-blind, placebo-controlled study. Sci. Rep. 2017, 7, 8905. [CrossRef] 
131. Hall, S.C.; Agrawal, D.K. Vitamin D and Bronchial Asthma: An Overview of Data from the Past 5 Years. Clin. Ther. 2017, 39, 917-929. [CrossRef]

132. Reinehr, T.; Schnabel, D.; Wabitsch, M.; Bechtold-Dalla Pozza, S.; Buhrer, C.; Heidtmann, B.; Jochum, F.; Kauth, T.; Korner, A.; Mihatsch, W.; et al. Vitamin D supplementation after the second year of life: Joint position of the Committee on Nutrition, German Society for Pediatric and Adolescent Medicine (DGKJ e.V.), and the German Society for Pediatric Endocrinology and Diabetology (DGKED e.V.). Mol. Cell. Pediatr. 2019, 6, 3. [CrossRef] [PubMed]

133. Jolliffe, D.A.; Greenberg, L.; Hooper, R.L.; Griffiths, C.J.; Camargo, C.A., Jr.; Kerley, C.P.; Jensen, M.E.; Mauger, D.; Stelmach, I.; Urashima, M.; et al. Vitamin D supplementation to prevent asthma exacerbations: A systematic review and meta-analysis of individual participant data. Lancet Respir. Med. 2017, 5, 881-890. [CrossRef]

134. Martineau, A.R.; Cates, C.J.; Urashima, M.; Jensen, M.; Griffiths, A.P.; Nurmatov, U.; Sheikh, A.; Griffiths, C.J. Vitamin D for the management of asthma. Cochrane Database Syst. Rev. 2016, 9, CD011511. [CrossRef] [PubMed]

135. Urashima, M.; Segawa, T.; Okazaki, M.; Kurihara, M.; Wada, Y.; Ida, H. Randomized trial of vitamin D supplementation to prevent seasonal influenza a in schoolchildren. Am. J. Clin. Nutr. 2010, 91, 1255-1260. [CrossRef] [PubMed]

136. Urashima, M.; Mezawa, H.; Noya, M.; Camargo, C.A., Jr. Effects of vitamin D supplements on influenza a illness during the 2009 H1N1 pandemic: A randomized controlled trial. Food Funct. 2014, 5, 2365-2370. [CrossRef] [PubMed]

137. Martineau, A.R.; Jolliffe, D.A.; Hooper, R.L.; Greenberg, L.; Aloia, J.F.; Bergman, P.; Dubnov-Raz, G.; Esposito, S.; Ganmaa, D.; Ginde, A.A.; et al. Vitamin D supplementation to prevent acute respiratory tract infections: Systematic review and meta-analysis of individual participant data. BMJ 2017, 356, i6583. [CrossRef] [PubMed]

138. Martineau, A.R.; Jolliffe, D.A.; Greenberg, L.; Aloia, J.F.; Bergman, P.; Dubnov-Raz, G.; Esposito, S.; Ganmaa, D.; Ginde, A.A.; Goodall, E.C.; et al. Vitamin D supplementation to prevent acute respiratory infections: Individual participant data meta-analysis. Health Technol. Assess. 2019, 23, 1-44. [CrossRef] [PubMed]

139. Yakoob, M.Y.; Salam, R.A.; Khan, F.R.; Bhutta, Z.A. Vitamin D supplementation for preventing infections in children under five years of age. Cochrane Database Syst. Rev. 2016, 11, CD008824. [CrossRef]

140. Aglipay, M.; Birken, C.S.; Parkin, P.C.; Loeb, M.B.; Thorpe, K.; Chen, Y.; Laupacis, A.; Mamdani, M.; Macarthur, C.; Hoch, J.S.; et al. Effect of High-Dose vs Standard-Dose Wintertime Vitamin D Supplementation on Viral Upper Respiratory Tract Infections in Young Healthy Children. JAMA 2017, 318, 245-254. [CrossRef]

141. Correa-Rodriguez, M.; Carrillo-Avila, J.A.; Schmidt-RioValle, J.; Gonzalez-Jimenez, E.; Vargas, S.; Martin, J.; Rueda-Medina, B. Genetic association analysis of vitamin D receptor gene polymorphisms and obesity-related phenotypes. Gene 2018, 640, 51-56. [CrossRef]

142. Olson, M.L.; Maalouf, N.M.; Oden, J.D.; White, P.C.; Hutchison, M.R. Vitamin D deficiency in obese children and its relationship to glucose homeostasis. J. Clin. Endocrinol. Metab. 2012, 97, 279-285. [CrossRef]

143. Smotkin-Tangorra, M.; Purushothaman, R.; Gupta, A.; Nejati, G.; Anhalt, H.; Ten, S. Prevalence of vitamin D insufficiency in obese children and adolescents. J. Pediatr. Endocrinol. Metab. 2007, 20, 817-823. [CrossRef] [PubMed]

144. Nsiah-Kumi, P.A.; Erickson, J.M.; Beals, J.L.; Ogle, E.A.; Whiting, M.; Brushbreaker, C.; Borgeson, C.D.; Qiu, F.; Yu, F.; Larsen, J.L. Vitamin D insufficiency is associated with diabetes risk in Native American children. Clin. Pediatr. 2012, 51, 146-153. [CrossRef] [PubMed]

145. Roth, C.L.; Elfers, C.; Kratz, M.; Hoofnagle, A.N. Vitamin d deficiency in obese children and its relationship to insulin resistance and adipokines. J. Obes. 2011, 2011, 495101. [CrossRef] [PubMed]

146. Poomthavorn, P.; Saowan, S.; Mahachoklertwattana, P.; Chailurkit, L.; Khlairit, P. Vitamin D status and glucose homeostasis in obese children and adolescents living in the tropics. Int. J. Obes. 2012, 36, 491-495. [CrossRef] [PubMed]

147. Bril, F.; Maximos, M.; Portillo-Sanchez, P.; Biernacki, D.; Lomonaco, R.; Subbarayan, S.; Correa, M.; Lo, M.; Suman, A.; Cusi, K. Relationship of vitamin D with insulin resistance and disease severity in non-alcoholic steatohepatitis. J. Hepatol. 2015, 62, 405-411. [CrossRef] 
148. Liu, D.; Fernandez, B.O.; Hamilton, A.; Lang, N.N.; Gallagher, J.M.C.; Newby, D.E.; Feelisch, M.; Weller, R.B. UVA irradiation of human skin vasodilates arterial vasculature and lowers blood pressure independently of nitric oxide synthase. J. Investig. Dermatol. 2014, 134, 1839-1846. [CrossRef]

149. Tangpricha, V.; Flanagan, J.N.; Whitlatch, L.W.; Tseng, C.C.; Chen, T.C.; Holt, P.R.; Lipkin, M.S.; Holick, M.F. 25-hydroxyvitamin D-1alpha-hydroxylase in normal and malignant colon tissue. Lancet 2001, 357, 1673-1674. [CrossRef]

150. Mawer, E.B.; Hayes, M.E.; Heys, S.E.; Davies, M.; White, A.; Stewart, M.F.; Smith, G.N. Constitutive synthesis of 1,25-dihydroxyvitamin $\mathrm{D}_{3}$ by a human small cell lung cancer cell line. J. Clin. Endocrinol. Metab. 1994, 79, 554-560. [PubMed]

151. Cross, H.S.; Bareis, P.; Hofer, H.; Bischof, M.G.; Bajna, E.; Kriwanek, S.; Bonner, E.; Peterlik, M. 25-Hydroxyvitamin D(3)-1alpha-hydroxylase and vitamin D receptor gene expression in human colonic mucosa is elevated during early cancerogenesis. Steroids 2001, 66, 287-292. [CrossRef]

152. Fouda, A.; Kandil, S.; Boujettif, K.; Fayea, N. Hypovitamininosis D in Childhood Cancer Survivors: Importance of Vitamin D Supplementation and Measurement Over Different Points of Time. J. Pediatr. Hematol. Oncol. 2018, 40, e83-e90. [CrossRef] [PubMed]

153. Demirsoy, U.; Sarper, N.; Aylan Gelen, S.; Zengin, E.; Kum, T.; Demir, H. The Association of Oral Vitamin D and Calcium Supplementation with Bone Mineral Density in Pediatric Acute Lymphoblastic Leukemia Patients. J. Pediatr. Hematol. Oncol. 2017, 39, 287-292. [CrossRef] [PubMed]

154. Genc, D.B.; Vural, S.; Yagar, G. The Incidence of and Factors Associated with Vitamin D Deficiency in Newly Diagnosed Children with Cancer. Nutr. Cancer 2016, 68, 756-761. [CrossRef] [PubMed]

155. Williams, J.D.; Aggarwal, A.; Swami, S.; Krishnan, A.V.; Ji, L.; Albertelli, M.A.; Feldman, B.J. Tumor Autonomous Effects of Vitamin D Deficiency Promote Breast Cancer Metastasis. Endocrinology 2016, 157, 1341-1347. [CrossRef] [PubMed]

156. Grant, W.B. An ecologic study of dietary and solar ultraviolet-B links to breast carcinoma mortality rates. Cancer 2002, 94, 272-281. [CrossRef] [PubMed]

157. Bodiwala, D.; Luscombe, C.J.; French, M.E.; Liu, S.; Saxby, M.F.; Jones, P.W.; Ramachandran, S.; Fryer, A.A.; Strange, R.C. Susceptibility to prostate cancer: Studies on interactions between UVR exposure and skin type. Carcinogenesis 2003, 24, 711-717. [CrossRef] [PubMed]

158. Pritchard, R.S.; Baron, J.A.; de Verdier, M.G. Dietary calcium, vitamin, D.; and the risk of colorectal cancer in Stockholm, Sweden. Cancer Epidemiol. Biomark. Prev. 1996, 5, 897-900.

159. Gandini, S.; Gnagnarella, P.; Serrano, D.; Pasquali, E.; Raimondi, S. Vitamin D receptor polymorphisms and cancer. Adv. Exp. Med. Biol. 2014, 810, 69-105.

160. Kazemian, E.; Akbari, M.E.; Moradi, N.; Gharibzadeh, S.; Mondul, A.M.; Jamshidi-Naeini, Y.; Khademolmele, M.; Zarins, K.R.; Ghodoosi, N.; Amouzegar, A.; et al. Vitamin D Receptor Genetic Variation and Cancer Biomarkers among Breast Cancer Patients Supplemented with Vitamin $\mathrm{D}_{3}$ : A Single-Arm Non-Randomized Before and After Trial. Nutrients 2019, 11, 1264. [CrossRef]

161. Jacobs, E.T.; Kohler, L.N.; Kunihiro, A.G.; Jurutka, P.W. Vitamin D and Colorectal, Breast, and Prostate Cancers: A Review of the Epidemiological Evidence. J. Cancer 2016, 7, 232-240. [CrossRef] [PubMed]

162. Yin, L.; Grandi, N.; Raum, E.; Haug, U.; Arndt, V.; Brenner, H. Meta-analysis: Serum vitamin D and breast cancer risk. Eur. J. Cancer 2010, 46, 2196-2205. [CrossRef] [PubMed]

163. Kim, Y.; Je, Y. Vitamin D intake, blood 25(OH)D levels, and breast cancer risk or mortality: A meta-analysis. Br. J. Cancer 2014, 110, 2772-2784. [CrossRef] [PubMed]

164. Gandini, S.; Boniol, M.; Haukka, J.; Byrnes, G.; Cox, B.; Sneyd, M.J.; Mullie, P.; Autier, P. Meta-analysis of observational studies of serum 25-hydroxyvitamin D levels and colorectal, breast and prostate cancer and colorectal adenoma. Int. J. Cancer 2011, 128, 1414-1424. [CrossRef] [PubMed]

165. Deschasaux, M.; Souberbielle, J.C.; Latino-Martel, P.; Sutton, A.; Charnaux, N.; Druesne-Pecollo, N.; Galan, P.; Hercberg, S.; Le Clerc, S.; Kesse-Guyot, E.; et al. Weight Status and Alcohol Intake Modify the Association between Vitamin D and Breast Cancer Risk. J. Nutr. 2016, 146, 576-585. [CrossRef]

166. Chlebowski, R.T.; Johnson, K.C.; Kooperberg, C.; Pettinger, M.; Wactawski-Wende, J.; Rohan, T.; Rossouw, J.; Lane, D.; O'Sullivan, M.J.; Yasmeen, S.; et al. Calcium plus vitamin D supplementation and the risk of breast cancer. J. Natl. Cancer Inst. 2008, 100, 1581-1591. [CrossRef] 
167. Cadeau, C.; Fournier, A.; Mesrine, S.; Clavel-Chapelon, F.; Fagherazzi, G.; Boutron-Ruault, M.C. Interaction between current vitamin $\mathrm{D}$ supplementation and menopausal hormone therapy use on breast cancer risk: Evidence from the E3N cohort. Am. J. Clin. Nutr. 2015, 102, 966-973. [CrossRef]

168. Madden, J.M.; Murphy, L.; Zgaga, L.; Bennett, K. De novo vitamin D supplement use post-diagnosis is associated with breast cancer survival. Breast Cancer Res. Treat. 2018, 172, 179-190. [CrossRef]

169. Crew, K.D.; Anderson, G.L.; Hershman, D.L.; Terry, M.B.; Tehranifar, P.; Lew, D.L.; Yee, M.; Brown, E.A.; Kairouz, S.S.; Kuwajerwala, N.; et al. Randomized Double-Blind Placebo-Controlled Biomarker Modulation Study of Vitamin D in Premenopausal Women at High Risk for Breast Cancer (SWOG S0812). Cancer Prev. Res. 2019. [CrossRef]

170. Manson, J.E.; Cook, N.R.; Lee, I.M.; Christen, W.; Bassuk, S.S.; Mora, S.; Gibson, H.; Gordon, D.; Copeland, T.; D'Agostino, D.; et al. Vitamin D Supplements and Prevention of Cancer and Cardiovascular Disease. N. Engl. J. Med. 2019, 380, 33-44. [CrossRef]

171. Yin, L.; Grandi, N.; Raum, E.; Haug, U.; Arndt, V.; Brenner, H. Meta-analysis: Serum vitamin D and colorectal adenoma risk. Prev. Med. 2011, 53, 10-16. [CrossRef] [PubMed]

172. Wei, M.Y.; Garland, C.F.; Gorham, E.D.; Mohr, S.B.; Giovannucci, E. Vitamin D and prevention of colorectal adenoma: A meta-analysis. Cancer Epidemiol. Biomark. Prev. 2008, 17, 2958-2969. [CrossRef] [PubMed]

173. Jacobs, E.T.; Hibler, E.A.; Lance, P.; Sardo, C.L.; Jurutka, P.W. Association between circulating concentrations of 25(OH)D and colorectal adenoma: A pooled analysis. Int. J. Cancer 2013, 133, 2980-2988. [CrossRef] [PubMed]

174. Garland, C.F.; Gorham, E.D. Dose-response of serum 25-hydroxyvitamin D in association with risk of colorectal cancer: A meta-analysis. J. Steroid Biochem. Mol. Biol. 2017, 168, 1-8. [CrossRef] [PubMed]

175. Ma, Y.; Zhang, P.; Wang, F.; Yang, J.; Liu, Z.; Qin, H. Association between vitamin D and risk of colorectal cancer: A systematic review of prospective studies. J. Clin. Oncol. 2011, 29, 3775-3782. [CrossRef] [PubMed]

176. Sheng, S.; Chen, Y.; Shen, Z. Correlation between polymorphism of vitamin D receptor TaqI and susceptibility to colorectal cancer: A meta-analysis. Medicine 2017, 96, e7242. [CrossRef] [PubMed]

177. He, Y.; Timofeeva, M.; Farrington, S.M.; Vaughan-Shaw, P.; Svinti, V.; Walker, M.; Zgaga, L.; Meng, X.; Li, X.; Spiliopoulou, A.; et al. Exploring causality in the association between circulating 25-hydroxyvitamin D and colorectal cancer risk: A large Mendelian randomisation study. BMC Med. 2018, 16, 142. [CrossRef]

178. Grau, M.V.; Baron, J.A.; Sandler, R.S.; Haile, R.W.; Beach, M.L.; Church, T.R.; Heber, D. Vitamin D calcium supplementation, and colorectal adenomas: Results of a randomized trial. J. Natl. Cancer Inst. 2003, 95, 1765-1771. [CrossRef]

179. Gao, Y.; Um, C.Y.; Fedirko, V.; Rutherford, R.E.; Seabrook, M.E.; Barry, E.L.; Baron, J.A.; Bostick, R.M. Effects of supplemental vitamin $\mathrm{D}$ and calcium on markers of proliferation, differentiation, and apoptosis in the normal colorectal mucosa of colorectal adenoma patients. PLOS ONE 2018, 13, e0208762. [CrossRef]

180. Horvath, H.C.; Lakatos, P.; Kosa, J.P.; Bacsi, K.; Borka, K.; Bises, G.; Nittke, T.; Hershberger, P.A.; Speer, G.; Kallay, E. The candidate oncogene CYP24A1: A potential biomarker for colorectal tumorigenesis. J. Histochem. Cytochem. 2010, 58, 277-285. [CrossRef]

181. Wactawski-Wende, J.; Kotchen, J.M.; Anderson, G.L.; Assaf, A.R.; Brunner, R.L.; O'Sullivan, M.J.; Margolis, K.L.; Ockene, J.K.; Phillips, L.; Pottern, L.; et al. Calcium plus vitamin D supplementation and the risk of colorectal cancer. N. Engl. J. Med. 2006, 354, 684-696. [CrossRef] [PubMed]

182. Autier, P.; Mullie, P.; Macacu, A.; Dragomir, M.; Boniol, M.; Coppens, K.; Pizot, C. Effect of vitamin D supplementation on non-skeletal disorders: A systematic review of meta-analyses and randomised trials. Lancet Diabetes Endocrinol. 2017, 5, 986-1004. [CrossRef]

183. Calderwood, A.H.; Baron, J.A.; Mott, L.A.; Ahnen, D.J.; Bostick, R.M.; Figueiredo, J.C.; Passarelli, M.N.; Rees, J.R.; Robertson, D.J.; Barry, E.L. No Evidence for Posttreatment Effects of Vitamin D and Calcium Supplementation on Risk of Colorectal Adenomas in a Randomized Trial. Cancer Prev. Res. 2019, 12, $295-304$. [CrossRef] [PubMed]

184. Baron, J.A.; Barry, E.L.; Ivanova, A. Calcium and Vitamin D for the Prevention of Colorectal Adenomas. N. Engl. J. Med. 2016, 374, 791-792. [CrossRef] [PubMed]

185. Urashima, M.; Ohdaira, H.; Akutsu, T.; Okada, S.; Yoshida, M.; Kitajima, M.; Suzuki, Y. Effect of Vitamin D Supplementation on Relapse-Free Survival among Patients with Digestive Tract Cancers: The AMATERASU Randomized Clinical Trial. JAMA 2019, 321, 1361-1369. [CrossRef] [PubMed] 
186. Ng, K.; Nimeiri, H.S.; McCleary, N.J.; Abrams, T.A.; Yurgelun, M.B.; Cleary, J.M.; Rubinson, D.A.; Schrag, D.; Miksad, R.; Bullock, A.J.; et al. Effect of High-Dose vs Standard-Dose Vitamin $\mathrm{D}_{3}$ Supplementation on Progression-Free Survival among Patients with Advanced or Metastatic Colorectal Cancer: The SUNSHINE Randomized Clinical Trial. JAMA 2019, 321, 1370-1379. [CrossRef] [PubMed]

187. Tuohimaa, P.; Tenkanen, L.; Ahonen, M.; Lumme, S.; Jellum, E.; Hallmans, G.; Stattin, P.; Harvei, S.; Hakulinen, T.; Luostarinen, T.; et al. Both high and low levels of blood vitamin D are associated with a higher prostate cancer risk: A longitudinal, nested case-control study in the Nordic countries. Int. J. Cancer 2004, 108, 104-108. [CrossRef] [PubMed]

188. Petrou, S.; Mamais, I.; Lavranos, G.; Tzanetakou, P.T.; Chrysostomou, S. Effect of Vitamin D Supplementation in Prostate Cancer: A Systematic Review of Randomized Control Trials. Int. J. Vitam. Nutr. Res. 2018, 88, 100-112. [CrossRef] [PubMed]

(C) 2019 by the authors. Licensee MDPI, Basel, Switzerland. This article is an open access article distributed under the terms and conditions of the Creative Commons Attribution (CC BY) license (http://creativecommons.org/licenses/by/4.0/). 